University of Chicago Law School

Chicago Unbound

Journal Articles

Faculty Scholarship

1979

\title{
Relaxation of Implementation Plans under the 1977 Clean Air Act Amendments
}

David P. Currie

Follow this and additional works at: https://chicagounbound.uchicago.edu/journal_articles

Part of the Law Commons

\section{Recommended Citation}

David P. Currie, "Relaxation of Implementation Plans under the 1977 Clean Air Act Amendments," 78 Michigan Law Review 155 (1979).

This Article is brought to you for free and open access by the Faculty Scholarship at Chicago Unbound. It has been accepted for inclusion in Journal Articles by an authorized administrator of Chicago Unbound. For more information, please contact unbound@law.uchicago.edu. 


\title{
RELAXATION OF IMPLEMENTATION PLANS UNDER THE 1977 CLEAN AIR ACT AMENDMENTS
}

\author{
David P. Currie*
}

\section{INTRODUCTION}

Though the Clean Air Act gives the Environmental Protection Agency considerable powers to regulate both mobile and stationary air-pollution sources directly, ${ }^{1}$ everyday control of most existing stationary sources remains subject to an awkward joint federal-state program based on ambient air-quality standards. ${ }^{2}$ The core of this program is section 109, under which the EPA promulgates primary air-quality standards "requisite to protect the public health" and secondary standards "requisite to protect the public welfare from any known or anticipated adverse effects." 3 Under section 110, the states then submit plans to the EPA for "attainment and maintenance" of the primary standards within three years and of the secondary standards within "a reasonable time."4

The most striking feature of this scheme is its absoluteness: Sec-

- Harry N. Wyatt Professor of Law, University of Chicago; Chairman, Illinois Pollution Control Board, 1970-1972. A.B. 1957, University of Chicago; LL.B. 1960, Harvard University.-Ed. My thanks to Mark Reinhardt, J.D. 1978, Chicago, and to Scott Bieber, J.D. 1979, Chicago, for thoughtful papers that helped shape my thinking on this subject. This Article is part of a forthcoming book on the Clean Air Act as a whole.

I. E.g., 42 U.S.C. $\$ \S 7411,7412,7521,7603$ (Supp. I 1977). See Currie, The Mobile-Source Provisions of the Clean Air Act, 46 U. CHI. L. REv. 811 (1979); Currie, Direct Federal Regulation of Stationary Sources Under the Clean Air Act, - U. PA. L. REv.- - (1980) (forthcoming). Congressional efforts to clean the air have a longer history than one might suspect. The first significant piece of legislation on the subject was the Clean Air Act of 1955, Pub. L. 84-159, ch. 360,69 Stat. 322, July 14, 1955 (originally codified at 42 U.S.C. $\$ \$ 1857-1858$ ). After periodic revisions, Congress overhauled the Act with the Clean Air Amendments of 1970, Pub. L. 91604, 84 Stat. 1676, Dec. 31, 1970 (formerly codified at 42 U.S.C. $\$ \S 1857-1858$ ) [hereinafter cited as Clean Air Amendments of 1970]. In 1977, Congress revamped the Act again. Clean Air Act Amendments of 1977, Pub. L. 95-95, 91 Stat 685, Aug. 7, 1977 (recodified at 42 U.S.C. $\$ \S 7401-7642$ (Supp. I 1977)) [hereinafter cited as Clean Air Act Amendments of 1977]. As its name implies, this Article scrutinizes these latest congressional efforts.

2. For a detailed exploration of the relevant provisions as they stood before the 1977 amendments, see Currie, Federal Air-Quality Standards and Their Implementation, 1976 A.B.F. RES. J. 365.

3. Clean Air Amendments of 1970, $\S 109$, as amended by Clean Air Act Amendments of 1977, § 106, 42 U.S.C. $\$ 7409$ (Supp. I 1977).

4. Clean Air Amendments of 1970, § 110, as amended by Clean Air Act Amendments of 1977, § 107, 42 U.S.C. $\$ 7410$ (Supp. I 1977). 
tions 109 and 110 flatly command that all adverse effects of air pollution be eliminated without regard to cost, and the Senate Committee in 1970 coldly confirmed this conclusion: "[E]xisting sources of pollutants either should meet the standard of the law or be closed down. ..."5 The Supreme Court in dictum agreed: "Section $110(a)(2)(A)$ 's three-year deadline for achieving primary air quality standards . . . leaves no room for claims of technological or economic feasibility."6

The harshness of the statutory requirements was dramatized by their implications for Los Angeles, which in the warmer months would have had to reduce vehicle travel by eighty-two percent to meet the primary ambient standard for photochemical oxidants by the statutory deadline of $1975 . .^{7}$ Without minimizing the desirability of eliminating Los Angeles smog, ${ }^{8}$ one might wonder whether it would be worth the cost of shutting the city down.

Nevertheless, following the plain command of section $110(a)(2)(A)$, the EPA promulgated gasoline-rationing regulations for California, and the Ninth Circuit duly upheld them: "[H]aving recognized that no alternative exists which is capable of attaining the requisite standards, petitioners have implicitly accepted the necessity of this regulation." "Yet the EPA responded to its victory by revoking the rationing requirement, reasoning that its enforcement would have "extremely adverse social and economic consequences" and noting that both houses of Congress, by passing separate bills that if enacted would have afforded relief, had "affirmatively expressed their desire" that Los Angeles be spared. At the same time, the EPA steadfastly maintained that it would not generally accept cost as an excuse for ignoring the clear statutory command; this was a "special case." 10

The Los Angeles accommodation underscored the failure of Congress to make adequate provision for ameliorating even the most ruinous costs of achieving rigid air quality standards. Of necessity, legislators write statutes to fit typical cases, and pollution statutes commonly contain an escape valve that authorizes variances when

5. S. Rep. No. 1196, 91 st Cong., 2d Sess. 3 (1970).

6. Union Elec. Co. v. Environmental Protection Agency, 427 U.S. 246, 258 (1976).

7. See 38 Fed. Reg. 2194-2200 (1973).

8. See U.S. Dept. of Health, Education, and Welfare, Air Quality Criteria for Photochemical Oxidants passim (NAPCA Pub. No. AP-63 (1970)).

9. City of Santa Rosa v. Environmental Protection Agency, 534 F.2d 150, 154 (9th Cir. 1976).

10. See 41 Fed. Reg. 45565 (1976). See also 7 ENVIR. Rep. (BNA) 920 (1976). 
compliance would impose unreasonable hardship. ${ }^{11}$ Congress, however, did not follow this maxim in drafting the Clean Air Act. Although the 1970 Amendments contained two provisions allowing limited extensions of the deadlines relating to air-quality standards, both fell far short of protecting dischargers from being forced to take economically unreasonable action. Under section $110(\mathrm{e}),{ }^{12}$ which the 1977 Amendments left intact, the EPA Administrator may extend the date for compliance with a primary standard for not more than two years; under former section $110(f),{ }^{13}$ which was repealed in 1977 , he could postpone the applicability of an implementation-plan requirement to an individual source for not more than one year. In neither case, however, had the affected polluter any right to invoke the remedy: The governor had to make the request, and politics might preclude his doing so in a deserving case. Moreover, neither provision clearly made unreasonable cost a basis for relief: The Administrator had to be convinced that the necessary technology was "not available" in time to meet the standard and, in the case of section $110(\mathrm{f})$, that continued operation of the polluting source was "essential to national security or to the public health or welfare." 14 Although Los Angeles received an extension to 1977 under section 110(e), the consensus has been that it was not renewable; yet compliance was just as unthinkable in 1977 as in 1975.15

Courts and administrators, however, generally find ways around unreasonable statutory requirements, and the Clean Air Act was no exception. In the case of Los Angeles, for instance, the EPA simply cast aside the troublesome rationing provisions, section 110's commands notwithstanding. ${ }^{16}$ Other sections of the Act, however, may have offered more defensible escape hatches. Section 113, in providing that the Administrator "may" issue an enforcement order to seek (1973).

11. See, e.g., Environmental Protection Act $\S 35$, IlL. Rev. Stat. ch. 111 1/2, § 1035

12. 42 U.S.C. $\$ 7410$ (e) (Supp. I 1977).

13. 42 U.S.C. \& 1857c-5(e)(1) \& (f)(1) (1976) (repealed 1977).

14. For discussion of these provisions, see Currie, supra note 2, at 380-85.

15. State variances offered no means of escape for Los Angeles. After considerable litigation, the Supreme Court foreclosed that route in Train v. Natural Resources Defense Council, 421 U.S. 60 (1975), holding that a state variance could be approved as a plan revision under $\$ 110(\mathrm{a})(3)(A)$ only if it did not interfere with the timely attainment of ambient standards. The House Committee in 1977 declared its intention "to confirm the correctness of the Supreme Court's opinion in the Train case." H.R. REP. No. 294, 95th Cong., 1st Sess. 57 (1977), reprinted in [1977] U.S. CODE CONG. \& AD. News 1077, 1135. The Sixth Circuit confirmed that Train survived the 1977 Amendments in Ohio Env. Council v. Environmental Protection Agency, 593 F.2d 24, 32-33 (6th Cir. 1979).

16. See text at notes 4-6 supra. 
judicial enforcement, ${ }^{17}$ appeared to afford the traditional flexibility of prosecutorial discretion. ${ }^{18}$ Moreover, section 113(a)(4) suggested another possibility for relief from undue hardship by directing the Administrator to specify a "reasonable" time for compliance in issuing an enforcement order. ${ }^{19}$ Despite an early court decision that "[s]ection 113 is simply not an appropriate vehicle . . . for . . . securing a variance," 20 the EPA took advantage of the apparent loophole, and the Supreme Court in Union Electric Co. v. EPA apparently endorsed that conduct: "Claims of technological or economic infeasibility, the Administrator agrees, are relevant to fashioning an appropriate compliance order under § 113(a)(4):"21

Such, then, was the sorry state of the law before 1977: a requirement that standards be set to achieve absolute freedom from adverse health effects, with wholly inadequate variance provisions and with relief provided under the table without either hearings or public participation. Congress responded by enacting the 1977 Amendments, which allow temporary relief from the Draconian deadlines of the 1970 Act, but still do not acknowledge the unpleasant possibility that total elimination of pollution's harmful effects may even in the long run not be worth the cost.

This Article probes the convoluted ameliorative provisions of the 1977 Amendments in three parts. Section I deals with delayed compliance orders - orders granted to stationary sources unable to meet the statutory deadlines for compliance. Section 113(d) is the fountainhead provision, and besides a general provision for delayed compliance, it also contains specific provisions for sources unable to comply due to retirement of present facilities, due to investment in innovative facilities with the promise of greater pollution reduction in the future or due to government orders to convert from cleaner fuels to coal.

Section II analyzes two specific relief provisions intended to go

17. Clean Air Amendments of 1970, supra note 1, § 113, 42 U.S.C. § $1857 \mathrm{c}-8$ (1976).

18. See United States v. United States Steel Corp., 9 Envir. Rep. Cas. 1002, 1003-05 (N.D. Ala. 1976). Cf. Bethlehem Steel Corp. v. Train, 544 F.2d 657, $659-60$ (3d Cir. 1976) (describing the EPA's practice under the 1972 version of the Water Pollution Control Act of issuing "Enforcement Compliance Schedule Letters" that fixed compliance deadlines, as a matter of "prosecutorial discretion," at a date later than that prescribed in the statute).

19. 42 U.S.C. \& 1957c-8(a)(4) (1976).

20. Getty Oil Co. (Eastern Operations) v. Ruckelshaus, 342 F. Supp. 1006, 1020 (D. Del. 1972). On appeal, the Third Circuit held there was no jurisdiction to consider the issue because in effect the plaintiff was challenging the validity of the implementation plan contrary to $\$ 307$ (b). Getty Oil Co. (Eastern Operations) v. Ruckelshaus, 467 F.2d 349 (3d Cir. 1972), cert. denied, 409 U.S. 1125 (1973). For criticism of this holding see Currie, Judicial Review Under Federal Pollution Laws, 62 Iowa L. Rev. 1221, 1254-58 (1977).

21. Union Elec. Co. v. Environmental Protection Agency, 427 U.S. 246, 268 (1976). 
beyond section 113(d). It first examines section 119, essentially a special delayed compliance order applicable only to nonferrous smelters. It then reviews the provisions in section 110 that grant temporary relief for energy and economic emergencies.

Section III examines the nonattainment provisions, which tackle the problem most graphically posed by Los Angeles: how to achieve and maintain ambient standards in areas suffering from excessive pollution, without bringing both new development and the economy to a standstill.

\section{Delayed Compliance Orders}

As congressional committees convened in 1977 to reconsider the provisions of the 1970 Clean Air Act, they acknowledged that some accommodation had to be made for the estimated 3500 major sources that had not met section 110 deadlines ${ }^{22}$ and that the old variance provision of section $110(f)$ was "too restrictive." 23 On the other hand, the Senate Committee found "no basis in law" for the EPA's practice of issuing orders for delayed compliance under section 113(a)(4), ${ }^{24}$ and neither committee thought that practice satisfactory on the merits. The House Committee complained that section 113 placed no limits on the length of time the Administrator might deem "unreasonable," did not require state approval for the delay, and provided no opportunity for public participation. ${ }^{25}$ The Senate Committee added that delayed compliance orders under the old section 113 left a discharger "subject to citizen suits and to potential inconsistent enforcement action taken by the Administrator." 26

The remedy was a new section 113(d), embodying a bewildering battery of prescriptions. The provision explicitly recognized delayed compliance orders for the first time:

A State (or, after thirty days notice to the State, the Administrator) may issue to any stationary source which is unable to comply with any requirement of an applicable implementation plan an order which specifies a date for final compliance with such requirement later than the date for attainment of any national ambient air quality standard specified in such plan if -

...

22. S. REP. No. 127, 95th Cong., 1st Sess. 45 (1977).

23. H.R. REP. No. 294, 95th Cong., 1st Sess. 56 (1977), reprinted in [1977] U.S. CoDE CONG. \& AD. NEwS 1077, 1134.

24. S. Rep. No. 127, 95th Cong., Ist Sess. 45 (1977).

25. H.R. REP. No. 294, 95th Cong., 1st Sess. 56 (1977), reprinted in [1977] U.S. CODE Cong. \& AD. NEws $1077,1134$.

26. S. Rep. No. 127, 95th Cong., Ist Sess. 45 (1977). 
(D) the order provides for final compliance . . . as expeditiously as practicable but . . . in no event later than July 1, 1979, or three years after the date for final compliance with such requirement specified in such plan, whichever is later . . . . 27

A delayed-compliance order (DCO) under the new section may be issued only after "notice to the public . . . and opportunity for public hearing" and must contain "a schedule and timetable for compliance" 28 as well as interim requirements for monitoring, reporting, and control, including measures to avoid "imminent and substantial endangerment to health of persons." 29 An order must warn any "major source" that a "noncompliance penalty" will be assessed if the new deadline is not met. ${ }^{30}$ Although the Administrator may issue a DCO without state consent, state and local authorities are free to demand "more expeditious ... compliance."31 On the other hand, no state may grant a DCO to a "major" source unless the Administrator affirmatively finds that the order was issued "in accordance with the requirements" of the Act, and he may veto any other state order if he determines that it was not so issued. ${ }^{32}$ If the Administrator "so objects," he "shall simultaneously proceed to issue" an enforcement order. ${ }^{33}$

The new section also revamped enforcement mechanisms to accommodate the new DCO's: An order issued under section 113(d) is a defense to any federal or private effort to compel earlier compliance. ${ }^{34}$ A state-issued order, but not a federal one, becomes "a part of the applicable implementation plan."35 Should a discharger violate a DCO, the Administrator "shall" enforce the offended requirement by suit or order, revoke the order after a record hearing, or sue for a noncompliance penalty, evidently without regard to duplication of any state enforcement efforts. ${ }^{36}$

27. Clean Air Act Amendments of 1977, $\$ 113$ (d), 42 U.S.C. $\S 7413$ (d) (Supp. I 1977).

28. 42 U.S.C. $\$ 7413$ (d)(1)(A) (Supp. I 1977).

29. 42 U.S.C. $\$ 7413(d)(7)(A)$ (Supp. I 1977).

30. See 42 U.S.C. $\$ 7413$ (d)(1)(E) (Supp. I 1977). Noncompliance penalties are set forth in 42 U.S.C. $\S 7420$ (Supp. I 1977).

31. 42 U.S.C. \& 7413(d)(2) (Supp. I 1977).

32. See 42 U.S.C. $\$ 7413$ (d)(2) (Supp. I 1977).

33. 42 U.S.C. $\$ 7413$ (d)(2) (Supp. I 1977). The EPA evidently interprets this direction to apply only to its actual veto of state orders for nonmajor sources, declaring that when it disapproves a major-source order it may either issue an order of its own or go directly to court. See EPA Environmental Policy Memorandum on Clean Air Act Section 113(a), (d) Orders, 9 ENVIR. REP. (BNA) 715, 718 (1978).

34. See 42 U.S.C. $\S 7413(d)(10)$ (Supp. I 1977).

35. 42 U.S.C. $\$ 7413$ (d)(11) (Supp. I 1977).

36. See 42 U.S.C. $\$ 7413$ (d)(9) (Supp. I 1977). A grandfather clause preserves orders under the old $\S 113$ to the extent consistent with the new law, and singles out for approval otherwise excessively long extensions previously granted to Louisville Gas \& Electric Co., in 
The new provision responds to the deficiencies of prior law identified by the committee reports. It is less restrictive than the old section $110(f)$ - it eliminates the necessity for a governor's request and it abandons the requirement that continued operation be "essential." Yet unlike the old section 113, it establishes time limits, it brings states prominently into the process, and it guarantees public participation through hearings. Furthermore, the section shields a source receiving an extension against collateral citizen and federal enforcement actions. Yet section 113(d) bristles with difficulties of its own, both of interpretation and of policy. I shall discuss them in the following sequence: (A) standards for DCO eligibility, (B) time limits, (C) degree of discretion, (D) hearing requirements, and (E) special provisions for retirement, innovation and coal conversion.

\section{A. The Standards for Eligibility}

Section $113(d)$ is remarkably uninformative about the requisites for allowing delayed compliance. In authorizing relief for any stationary source that is "unable to comply" with an implementationplan requirement, the statute fails to give clear answers to three obvious questions: whether one qualifies for an extension if his present inability to comply is the result of his own inexcusable conduct; whether a source is entitled to an extension if the means for compliance are available, but only at unreasonable cost; and whether inability to comply justifies an extension that would perpetuate an unreasonable health hazard.

\section{Good Faith}

On its face the requirement that a source be "unable to comply" imposes no requirement of good faith in past efforts to achieve timely compliance; the sole criterion seems to be present inability to meet the deadline. The EPA has accordingly held good faith irrelevant: A source is eligible for a DCO "regardless of its past history" so long as it is unable to comply. ${ }^{37}$ Three arguments underpin the Agency's interpretation. First, the explicit good-faith requirement of

appreciation of its willingness to help "demonstrate flue gas desulfurization technology." 42 U.S.C. § 7413(d)(12)(A)(B) (Supp. I 1977). See 123 Cong. Rec. H8664 (daily ed. Aug. 4, 1977) (clarifying statement), reprinted in [1977] U.S. CoDE CoNG. \& AD. News 1570, 1574. See also H.R. REP. No. 564, 95th Cong., 1st Sess. 134 (1977), reprinted in [1977] U.S. CODE CONG. \& AD. NEwS 1502, 1514.

37. See EPA Enforcement Policy Memorandum on Clean Air Act Section 113(a), (d), Orders, supra note 33 , at $718-19$. 
the old section $110(\mathrm{f}),{ }^{38}$ the predecessor provision, is conspicuously absent from section 113(d). ${ }^{39}$ Second, the silence of section 113 stands in stark contrast to section 120's provision excluding noncompliance penalties when the "inability to comply" "results from reasons entirely beyond the control of the owner or operator." 40 When read together, the two sections suggest that DCO's may be issued to sources unable to comply due to inadequate past efforts. Finally, the Senate Committee specifically rejected a test of prior good faith because it felt the requirement "would place an excessive burden on the manpower and resources of the States and EPA."41 All these considerations will probably lead courts to defer to the EPA's reasonable conclusion that good faith is not required. 42

Unfortunately, the absence of a good-faith requirement in sec-

38. Clean Air Amendments of 1970, $\S 110(f)$ (amended 1977) (current version at 42 U.S.C. $\S 1710$ (Supp. I 1977)).

39. See generally H.R. Rep. No. 294, 95th Cong., Ist Sess. 56 (1977), reprinted in [1977] U.S. Code CoNG. \& AD. News 1077, 1134.

40. Clean Air Act Amendments of 1977, sec. 118, § 120(a)(2)(B)(iv), at 42 U.S.C. $\S 7420(\mathrm{a})(2)(B)$ (iv) (Supp. I 1977).

41. S. REP. No. 127, 95th Cong., 1st Sess. 45-46 (1977).

42. The issue is not, however, entirely certain. When it first adopted $\S 113(d)$, Congress accepted "the Senate provision on issuance of enforcement orders," H.R. REP. No. 564, 95th Cong., 1st Sess. 133 (1977), reprinted in [1977] U.S. CODE CoNG. \& AD. NEws 1502, 1514. The Senate version, however, contained no reference to the requirement of inability to comply. Clean Air Act Amendments of 1977, supra note 1, \& 112; see S. REP. No. 127, 95th Cong., lst Sess. 46 (1977). A later "technical" amendment inserted the present "unable to comply" language from the House bill in order to remedy an "erroneous omission" from the original provision. Safe Drinking Water Amendments of 1977, Pub. L. 95-190, § 14(14), 91 Stat. 1393, 1400 (codified at 42 U.S.C. $§ 7413$ (d)(1) (Supp. I 1977)). See also 123 Cong. Rec. H11,954, H11,957 (daily ed. Nov. 1, 1977). The House Committee had given four specific examples of circumstances that would render a source "unable to comply": (1) means of compliance with the plan had not been "adequately demonstrated"; (2) means of compliance were unobtainable due to "shortage"; (3) compliance was prevented by "delay of replacement facilities"; or (4) compliance was not possible due to "such entirely uncontrollable events as embargoes, strikes, or natural disasters," H.R. REP. No. 294, 95th Cong., 1st Sess. 59-60 (1977), reprinted in [1977] U.S. CODE \& AD. NEwS 1077, 1137-38. Except for delay attributable to a replacement facility, these examples are all of factors over which the discharger is most unlikely to have any control. This pattern suggests that the Committee intended the delay of a replacement to be an excuse only if it was not due to the discharger's fault, and indeed that was the requirement of the earlier bill, H.R. 10498, 94th Cong., 1st Sess., § 103(c)(1)(D) (1975), from which the example was taken without indication of disagreement with its particulars. Thus, although the Committee did not intend the list to be exclusive, the illustrations do suggest that the Committee intended "inability to comply" to mean inability for reasons the discharger could not help, and therefore to sanction only extensions dependent on good faith.

Thus, Congress first adopted the Senate's language, which excluded good faith; then it adopted the House's language, which on its face confirms the Senate's intention, but which the House apparently intended to require good faith. However, since Congress adopted the House language without suggesting any awareness that it favored the House interpretation over the Senate's interpretation, since the Conference Committee had said it was adopting the Senate version, since the Committee was the more explicit in expressly rejecting a requirement of good faith, and since the Senate interpretation is the more natural reading of the final statutory language, I conclude that the statute does not require good faith. 
tion $113(d)$ may reward foot-dragging and place those who did comply with the onerous 1970 requirements at an unjust competitive disadvantage. Without a DCO, the polluter whose delay is the result of inadequate efforts could be socked with continuing penalties until he complied; but section 110(d)(1) expressly forbids any federal enforcement proceeding "based upon noncompliance during the period the order is in effect."43 Under section 120, a major source sometimes will have to pay a "noncompliance penalty" adequate to offset "the economic value" of unjustified delay beyond July 1, 1979, notwithstanding the existence of a DCO. ${ }^{44}$ But it seems unaccountable that Congress has allowed the miscreant to be spared penalties from the date of a DCO until mid-1979, or, in some cases, for a period thereafter. ${ }^{45}$

\section{Unreasonable Cost}

Pollution statutes typically accommodate economic as well as physical hardship; the apparent failure to do so, I have argued, was a major shortcoming of the pre-1977 variance provisions of section 110.46 For example, a brief extension for economic hardship could avoid expenditures for overtime labor or expedited delivery that might be exorbitant; a longer one could permit perfection of an economical alternative to prohibitively expensive existing technology, such as distillation of wastewater. 47

Whether section 113(d)(1)'s "unable to comply" standard embraces economic hardship is unclear. A neighboring provision, section 113(d)(4)(D), uses the term "impracticable,"48 which more

43. 42 U.S.C. \& 7413(d)(10) (Supp. I 1977). It does not forbid the infliction of penalties for violations committed before issuance of the order. Moreover, although final compliance with many emission requirements was not necessary before 1975 (and possibly not before 1977 in regions in which ambient deadlines were extended under $\S 110(\mathrm{e})$ ), penalties for violation of interim requirements such as purchasing equipment might accrue much earlier. However, the statute made provision for civil penalties only in 1977, see \& 113(b), 42 U.S.C. \& 7413(b) (Supp. I 1977), and they can hardly be made retroactive. Moreover, criminal sanctions seem to have proved ineffective. See S. Rep. No. 127 (1977), 95th Cong., Ist Sess. 52 (1977): "[F]ew criminal actions have been brought and great difficulties and delays have been encountered in these cases."

44. 42 U.S.C. $\$ 7420$ (Supp. I 1977). For example, penalties begin to run no later than the date of adoption of a post-1977 standard, while a DCO may allow three years from the date on which compliance is prescribed. Compare $\$ 7420(\mathrm{~g})$ with $\$ 7413(\mathrm{~d})(1)(\mathrm{D})$.

45. For example, if a standard adopted after mid-1977 allows less than three years for compliance, any DCO period within those three years appears to be free from penalties. 42 U.S.C. \& 7420 (Supp. I 1977).

46. See text at notes 1-21 supra.

47. See In re Effluent Criteria, 3 Ill. P.C.B. 401, 413 (1972), where a state board found distillation technologically available for removing chlorides and sulfates but declined to require it on grounds of cost.

48. 42 U.S.C. $\$ 7413$ (d)(4)(D) (Supp. I 1977). 
clearly includes considerations of cost, and the juxtaposition might suggest that Congress intended the distinction. Moreover, none of the examples of "inability" cited in the House Committee Report involved problems of cost; 49 and the Senate Committee, commenting on a bill that only prescribed compliance as soon as "practicable," nonetheless stated that delay could not be allowed "simply for convenience or for economic advantages which would accrue from delayed compliance."so

On the other hand, the requirement that compliance under a DCO be achieved as expeditiously as "practicable" 51 demonstrates that cost was to be a factor at least in determining the duration of an extension. It is hard to believe Congress meant to find the same consideration irrelevant in determining whether the extension should be granted at all. The word "unable" does not necessarily exclude cost considerations: While one is always physically able to comply by closing a factory, no one would argue that is what Congress had in mind. ${ }^{52}$ As for the legislative history, prohibitive or unreasonable cost may not be what the Senate Committee meant in rejecting "economic advantages," which sounds like a reference to ordinary profits. More significantly, the House Committee, commenting on the language found in the present statute, explicitly stated that both "economic and technical feasibility may be considered, under the conditions expressly provided for in the statute, including under a DCO application."53 Finally, the apparent absence of a good-faith requirement lends further support to the conclusion that cost may be considered: It seems unlikely that Congress perversely intended to grant relief to dischargers whose physical inability is their own fault but not to those facing unreasonable expenses beyond their control. The EPA and the courts should therefore construe "unable to comply" to include inability due to exorbitant costs, in accordance with the traditional and sensible variance criterion of unreasonable hard-

49. H.R. REP. No. 294, 95th Cong., 1st Sess. 56-60 (1977), reprinted in [1977] U.S. CODE CoNG. \& AD. NEws 1077, 1137-38.

50. S. REP. No. 127,95 th Cong., Ist Sess. 46 (1977).

51. 42 U.S.C. $\$ 7413$ (d)(1)(D) (Supp. I 1977).

52. Courts have used analogous reasoning in assessing cost considerations in other federal regulatory statutes. In the context of occupational health and safety, the D.C. Circuit has construed the term "feasible" - which is quite close to \& 113(d)'s "unable to comply" standard - to allow consideration of cost: "[I]t would comport with common usage to say that a standard that is prohibitively expensive is not 'feasible," "Industrial Union Dept. v. Hodgson, 499 F.2d 467, 477 (D.C. Cir. 1974) (construing $§ 6(b)(5)$ of the Occupational Safety and Health Act, 29 U.S.C. \& 655(b)(5) (1976)).

53. H.R. REP. No. 294, 95th Cong., Ist Sess. 68 (1977), reprinted in [1977] U.S. CODE CONG. \& AD. News 1077, 1146. 
ship. By inserting a single phrase, however, Congress could have spared us any doubts.

\section{The Extent of the Health Hazard}

As I have previously noted, the typical variance criterion is "unreasonable hardship," which allows a comparison of the costs and benefits of compliance. ${ }^{54}$ Section $113(\mathrm{~d})$, however, makes no reference to the benefits of compliance - anyone may receive an extension if "unable to comply." Yet one can certainly envision situations where a source that cannot otherwise comply should be shut down. For example, a source's emissions may be causing widespread disease or ruining a profitable nearby business, while the benefits of its operation are minimal. While the statute proscribes a DCO for any "imminent and substantial endangerment to health," it does not foreclose issuance of a DCO in other cases of unreasonable harm. Congress should have made clear that no variance may be permitted unless the cost of immediate compliance significantly outweighs the benefits.

\section{B. The Time Limit}

An order under section 113(d) must call for compliance "as expeditiously as practicable." Thus, the statute quite sensibly allows the extent of hardship to determine the duration of relief. However, the section places specific limits on the length of time practicability may demand. The Senate bill contained a flat 1979 deadline; the House bill would have limited the "aggregate" of extensions to five years beyond "the date on which, but for this section . . . compliance would have been required." 55 The provision adopted out of the Conference Committee incorporates elements of both bills. Except for certain special orders that I shall discuss below, compliance must come "in no event later than July 1, 1979, or three years after the date for final compliance with such requirement specified in such plan, whichever is later."56

At first glance this language, unlike that of the Senate and House bills, does not appear to impose an absolute deadline, for arguably the new date set in the section 113 order is itself a "requirement specified in [the] plan," from which a further extension may be granted. Section 113(d)(11) superficially appears to confirm this possibility:

54. See, e.g., Ill. Rev. Stat. ch. 111 1/2, \& 1035 (1973).

55. H.R. Rep. No. 294, 95th Cong., 1st Sess. 370 (1977); see S. Rep. No. 127, 95th Cong., 1st Sess. 166 (1977).

56. 42 U.S.C. $\$ 7413(d)(1)(d)$ (Supp. I 1977). 
"any order issued by the State and in effect pursuant to this subsection shall become part of the applicable state plan."57 It does so, however, only "for the purposes of sections 110,304, and 307," not for purposes of section 113(d) itself. This provision, which existed in the Senate bill, ${ }^{58}$ seems to have been designed to assure citizen enforcement and judicial review of delayed-compliance orders, not to sanction repeated extensions. The Conference Committee indicated its adherence to the absolute deadlines of both bills: "Orders are limited to not more than 3 years delay ...."59 Finally, as the Supreme Court said in Union Electric, the function of a conference committee is to reconcile differences between House and Senate bills, not to depart from their common provisions. ${ }^{60}$ Hence the date specified in an earlier section 113(d) order is not one "specified in [the] plan" within the meaning of that section, and therefore such an order may not be renewed. ${ }^{61}$

Having concluded that the time limitation is absolute, I think it misguided. The House Committee gave a number of reasons for it: The importance of protecting health, the risk of abuse of administrative discretion, the desirability of an incentive for developing technology, and the belief that "5 years would be the maximum . . . extension ... needed in most instances." 62 Even disregarding the provision's failure to afford a full five years to any source facing a deadline in 1975 or later, how can one be confident that five years will suffice for each of the more than 3500 noncomplying sources, without exploring their varying circumstances and without clairvoyance about what new impediments will arise during the next five years? The purpose of any variance provision is to accommodate cases not fitting the general pattern; it should not itself be procrustean. Health is of course important, but section 113(d) recognizes that countervailing considerations may predominate before 1979; I see no reason to think they might not do so in some cases thereafter. "Technology-forcing" is fine, but the discharger may be in no posi-

57. 42 U.S.C. $\$ 7413$ (d)(11) (Supp. I 1977).

58. See S. Rep. No. 127, 95th Cong., 1st Sess. 168 (1977).

59. H.R. REP. No. 564, 95th Cong., 1st Sess. 133 (1977), reprinted in [1977] U.S. CoDE CONG. \& AD. NEWS 1502, 1514.

60. See Union Elec. Co. v. Environmental Protection Agency, 427 U.S. 246, 262-63 (1976).

61. The three-year provision could be invoked to provide a post-1979 date if the plan itself (as revised, for example, or to implement a new air-quality standard) provided for compliance after July 1, 1976. See also EPA Enforcement Policy Memorandum on Clean Air Act Section 113(a), (d) Orders, supra note 33 , at $720 \& \mathrm{n} .^{*}$ (\$ 110 (e) extension and plan readopted after invalidation by court).

62. H.R. REP. No. 294, 95th Cong., 1st Sess. 64-65 (1977), reprinted in [1977] U.S. CODE CONG. \& AD. NEWS 1077, 1142-43. 
tion to develop the necessary technology. Conditioning further extension on proof of the discharger's best efforts toward reducing emissions, or the rejected House provision requiring financial contributions toward the development of controls, ${ }^{63}$ would have served Congress's purpose without imposing the potential hardship of an inflexible schedule. A check on administrative abuse could have been provided, as in Illinois, ${ }^{64}$ by authorizing brief and renewable extensions conditioned on satisfactory progress, subject to legislative oversight. Instead, the wasteful process of still another congressional amendment, the remedy contemplated by the House Committee, ${ }^{65}$ seems virtually inevitable under section 113(d); it might well have been avoided if Congress had not been so extraordinarily mistrustful of the EPA's ability to administer a flexible standard.

\section{Discretion}

Section 113(d) provides that an extension "may" be issued to a source that cannot comply, not that it "shall" be. 66 Accordingly, the Agency has announced in its guidelines that it will not issue extensions to all who qualify. ${ }^{67}$ The legislative history confirms this interpretation. Both bills used the term "may." The Senate Report was silent on the question of discretion, but the House Report was explicit: "This section authorizes, but does not require, the issuance of a DCO . . . . Thus, a source which has borne the burden of providing $[$ sic $]$ its eligibility for . . a DCO . . . has not created any entitlement thereto."68

One might think that the need to allow relief for unreasonable hardship is so obvious that Congress should not have left the matter to the discretion of states and an administrative agency. Part of the answer lies in the delicate statutory balance of federal-state relations: a state may refuse to grant an extension because under section 116 it

63. H.R. REP. No. 294, 95th Cong., 1st Sess. 371-72 (1977).

64. See Ill. Rev. STAT. ch. $1111 / 2, \S \S 1035-1037$ (1973).

65. See H.R. REP. No. 294, 95th Cong., 1st Sess. 65 (1977), reprinted in [1977] U.S. CoDE CoNG. \& AD. News 1077, 1143.

66. 42 U.S.C. § 7413(d) (Supp. I 1977).

67. See EPA Enforcement Policy Memorandum on Clean Air Act Section 113(a), (d) Orders, supra note 33, at 715-16. The statutory language alone is not conclusive. The Illinois Pollution Control Board, for example, operating under a variance provision employing the same word "may," assumed the legislature had meant for those who qualified to be given relief, and the Illinois courts ordered variances granted when they found the Board's denial contrary to the manifest weight of the evidence. See Seegren v. Environmental Protection Agency, 8 Ill. App. 3d 1049, 291 N.E.2d 347 (1972).

68. H.R. REP. No. 294, 95th Cong., 1st Sess. 67 (1977), reprinted in [1977] U.S. CODE CONG. \& AD. NEws 1077, 1145. 
may impose standards more stringent than federal law requires. ${ }^{69}$ The House Committee justified giving the federal agency discretion by arguing that "the Administrator stands in a position of the State" 70 regarding a plan he has adopted and that discretion promotes the development of technology: "If an order were mandated whenever the conditions . . . were met, sources might be encouraged to devote their sole or primary effort to perfecting their case for an order, rather than to the task of research and development to make available the equipment needed to comply."71

This reasoning is quite unpersuasive. In relevant respects the Administrator does not stand in the same position as a state; he is the instrument of congressional policy, not another sovereign with independent responsibility to protect its people. As for technologyforcing, again I think Congress has carried its point too far. Technological advancement can be encouraged by making good-faith efforts to innovate a prerequisite for an extension, without conferring upon the Agency discretion to exact compliance despite unreasonable hardship. Indeed, the diversion of effort from research to litigation is likely to be just as great when an administrator defines who will be given a variance as when the statute does.

Nevertheless, the discretion conferred by section 113 (d) is a partial antidote to the overly lax threshold requirement of inability to comply with the plan. The states and the Administrator may limit extensions to situations where the cost of shutdown exceeds the benefits, or where commitments are made to develop technology, or where past efforts at compliance have been in good faith. Indeed, they are free to determine that no extensions will be allowed at all. ${ }^{72}$

Exercising this discretion, the EPA has announced that it will not grant a DCO to any source with "an egregious history of noncompliance, recalcitrance, or environmental harm" and has recommended that states adopt the same position. ${ }^{73}$ An earlier EPA statement had purported to require the states to do so, ${ }^{74}$ but the Agency abandoned the attempt in apparent recognition that the statute allows EPA disapproval of state orders only for failure to meet the statutory criteria

69. Id.

70. Id. at 68, reprinted in [1977] U.S. CODE CONG. \& AD. NEws 1077, 1146.

71. Id. at 67, reprinted in [1977] U.S. CODE CoNG. \& AD. News 1077, 1145.

72. The legislative history related in text at note 69 supra certainly supports this last possibility where a state is concerned, and the Administrator seems to possess powers at least equal to those of a state.

73. See EPA Enforcement Policy Memorandum on Clean Air Act Section 113(a), (d) Orders, supra note 33 , at 716-17.

74. 8 ENVIR. REP. (BNA) 1131-32 (1978). 
for eligibility. Instead, the EPA will seek penalties under section 113(b) for pre-DCO violations in cases where it would not have granted relief because of a history of recalcitrance. ${ }^{75}$ As I suggested earlier, a better solution would have been to allow the EPA to disapprove state orders on a finding of bad faith.

The delegation of discretionary variance authority in section 113(d) certainly improves the prior law, which essentially provided relief only under the table, and it is undoubtedly better than requiring variances without proof of unreasonable hardship. But I see no justification for empowering the EPA either to refuse relief to one who shows such hardship or to grant it to one who does not. Regrettably, section 113(d) seems to give it authority to do both.

\section{Hearings}

Delayed-compliance orders under the pre-1977 section 113 were issued not only without public participation, but also without any right of a hearing for the discharger. To rectify this shortcoming, the new section 113(d) requires "notice to the public . . . and opportunity for public hearing." 76

"Public hearing," a popular rulemaking requirement, ${ }^{77}$ commonly connotes the kind of hearing conducted by legislative committees. ${ }^{78}$ That is what the House Report had in mind, ${ }^{79}$ and that is how the EPA interprets the requirement. ${ }^{80}$ What Congress neglected to consider is that the decision whether or not to give an individual source more time is essentially adjudicative, not legislative. The issue may often be whether circumstances peculiar to a source - an explosion, a delay in delivery, unfavorable soil conditions - render it "unable to comply." 81 For questions like these, legislatures have often insisted on trial procedures, including cross-examination and decision on the basis of the hearing record. ${ }^{82}$

75. See EPA Enforcement Policy Memorandum on Clean Air Act Section 113(a), (d) Orders, supra note 33 , at 717 .

76. 42 U.S.C. $\S 7413$ (d)(1)(A) (Supp. I 1977).

77. See, e.g., ILL. REv. STAT. ch. I1I 1/2, § 1037 (1973).

78. See generally Currie, The Mobile-Source Provisions of the Clear Air Act, 46 U. CHI. L. REv. 811, 837-47 (1979).

79. H.R. ReP. No. 294, 95th Cong., 1st Sess. 58 (1977), reprinted in [1977] U.S. CODE CONG. \& AD. NEws 1077, 1136 ("an informal, legislative-type hearing").

80. See EPA Enforcement Policy Memorandum on Clean Air Act Section 113(a), (d) Orders, supra note 33, at 720; 43 Fed. Reg. 44522 (1978) (to be codified in 40 C.F.R. $§ 65.04$ ).

81. Regulations may make other adjudicative facts relevant, such as past efforts toward compliance, the degree of hardship a shutdown would cause, and the harm continued emissions from a particular source would do to the community.

82. See, e.g., Ill. Rev. Stat. ch. 111 1/2, § 1037 (1973). 
Quasi-judicial procedures would be well-suited to determining factual issues about an individual source, ${ }^{83}$ affording all concerned a full opportunity to present their case. ${ }^{84}$ Hence, Congress should amend the statute to require the state or Administrator to hold a quasi-judicial hearing before issuing a DCO. ${ }^{85}$

\section{E. Special Provisions for Retirement, Innovation, and Coal Conversion}

As if the provisions of section 113(d) already discussed were not sufficiently complicated, Congress added special provisions for three specific situations.

\section{Retirement}

Section 113(d)(3) authorized delayed-compliance orders permitting operation "until July 1, 1979, without any interim schedule of compliance," for "any source" that "intends to comply by means of replacement of the facility, a complete change in production process, or a termination of operation." The discharger had to post a "bond or other surety" "in an amount equal to the cost of actual compliance . . . and any economic value which may accrue to the owner or operator . . . by reason of the failure to comply." On failure to replace or retire the facility in accordance with the order, the owner or operator would forfeit the security without hope of compromise..$^{86}$

83. Often due process requires these procedures. For example, when a statute confers upon a person the right to practice law or to receive welfare payments, the Supreme Court has held that due process entails allowing a person meeting the statutory requirements to demand an adjudicative hearing with appropriate procedural safeguards, such as cross examination. See, e.g., Goldberg v. Kelly, 397 U.S. 254 (1970) (termination of welfare benefits); Willner v. Committee on Character \& Fitness, 373 U.S. 96 (1963) (bar admission). However, the due process clause protects only "life, liberty, or property," U.S. CoNST. amends. V \& XIV, \& 1. While the Supreme Court has held that "property" includes interests to which one is entitled upon meeting statutory qualifications, as in the bar admission and welfare cases, see Arnett v. Kennedy, 416 U.S. 134 (1974); Board of Regents v. Roth, 408 U.S. 564 (1972), discretion granted the Administrator to deny extensions to those meeting the statutory threshold, confirmed by express legislative history, should refute any argument of statutory entitlement to a delayed-compliance order: The House Committee flatly denied that the DCO provisions would create any "entitlement," H.R. REP. No. 294, 95th Cong., 1st Sess. 67 (1977), reprinted in [1977] U.S. CODE CONG. \& AD. NEws 1077, 1145. On the other hand, a property interest within the due process clauses may be created by regulation as well as by statute; thus, if the EPA or a state creates a right to a DCO, it might well be obliged to afford the discharger an adjudicative hearing to determine its eligibility.

84. Members of the affected public can be given their say in an adjudicative proceeding as well as in a legislative one. See, e.g., ILL. Rev. STAT. ch. 111 1/2, \& 1032 (1973).

85. The statute does not specify what procedure the EPA must follow in reviewing DCO's granted by a state. Present EPA regulations provide an opportunity for written comments and furnish explanatory material to the public. $43 \mathrm{Fed}$. Reg. 44522 (1978) (to be codified in 40 C.F.R. $\$ \S 65.04($ b) $\& 65.05)$.

86. 42 U.S.C. $\$ 7413(d)(3)$ (Supp. I 1977). 
The expiration of the 1979 deadline for retirement orders moots the interesting statutory-construction questions raised by this provision. ${ }^{87}$ But two policy issues remain: why a separate retirement provision was thought necessary in the first place, and why no retirement order could extend beyond July 1, 1979.

It makes sense in some cases to allow continued violation by a facility about to be taken out of service. A million-dollar precipitator might be a reasonable investment for thirty years of emission reduction and wholly unreasonable for three. ${ }^{88}$ Moreover, an extension might reduce pollution in the long run by stimulating investment in new facilities subject to stricter standards rather than makeshift improvements of outdated facilities. Yet these considerations fail to explain why a separate provision was required; unless costs and benefits are irrelevant under the general DCO provision, a plant nearing the end of its life might well qualify for an order as "unable" to comply. Nevertheless, Congress chose to distinguish retirement orders from ordinary DCO's in two important respects: including a bond requirement and omitting an interim compliance schedule. The justification for the distinctions, however, is not clear. Bonds can be a useful incentive to compliance: they are common conditions of extensions in Illinois. ${ }^{89}$ But it seems peculiar to limit their use to cases in which the source is to be retired rather than controlled. ${ }^{90}$ The omission of an interim schedule seems simply misguided: Interim deadlines could help to assure that the replacement facility is not unjustifiably delayed.

Moreover, the 1979 cutoff date for retirement orders appears entirely unjustified. As in the case of any other delayed-compliance order, there was no guarantee that compliance with existing plan requirements would cease to be an unreasonable hardship at that point; that million-dollar precipitator might not be worth five years' control either. More important, the potential for avoiding unreasonable hardship or encouraging new facilities by delaying compliance

87. Among them are the degree of discretion conferred by the use of the word "may," the apparent inclusion of mobile sources, and the computation of the bond amount, which arguably requires prediction as to the adverse effects and duration of a future violation.

88. See Mt. Carmel Pub. Util. v. Environmental Protection Agency, 3 Ill. P.C.B. 25 (1971).

89. See Currie, Enforcement Under the Illinois Pollution Law, 70 Nw. U. L. REv. 389, 471 n.402 (1975).

90. At the same time, Congress's insistence on complete forfeiture regardless of circumstance seems barbaric. One can imagine, for example, a natural disaster incapacitating a new electric generating plant designed to replace the facility scheduled for retirement. If the extension was properly granted to begin with, a shutdown depriving innocent citizens of electricity would be perverse; and enforcing substantial forfeiture for continued operation would not be much better. 
until retirement was not limited to plans currently in effect; if the retirement provision was a good idea for existing plans, it should have been a permanent part of the statute.

In short, I would not have made separate provision for extensions in cases of retirement or replacement of sources. Appropriately flexible provisions for bonds in administrable amounts should have been made for all delayed-compliance orders, interim schedules required whenever there was reason to monitor progress, and the standard for issuance made clearly broad enough to include retirement cases or any others of unreasonable hardship.

\section{Innovation}

Section 113(d)(4) allows up to five years' extension for any implementation-plan deadline for a stationary source willing to experiment with new technology. To qualify for the extension, the proposed method must satisfy several awkwardly worded conditions: (1) The control method must be "likely to be adequately demonstrated" by the time the order expires; (2) it must be "not likely to be employed" without the extension; (3) it must afford promise of greater emission reduction than "the means . . . which, but for such order, would be required," or an equivalent reduction at lower cost; and (4) compliance must be "impracticable" pending its installation. ${ }^{91}$ While most variances are granted to relieve hardship, section 113 (d)(4) is intended to encourage new technology.92 Thus, inability to comply on time is not required.

The House bill would have required the new technology to be "adequately demonstrated" at the time the order was entered, "to assure that the existence of purely theoretical, experimental, or speculative technology" would not suffice..$^{93}$ But since technology development needs the greatest encouragement at incipient stages, the House provision would have thwarted much of its own purpose. In contrast, the law as enacted, allowing an extension if the source can establish a likelihood that it will be able to demonstrate within the period of the order, alleviates this difficulty while remaining true to the House Committee's objections to delays that are not likely to produce results.

91. 42 U.S.C. $\$ 7413(d)(4)$ (Supp. I 1977).

92. H.R. REP. No. 294, 95th Cong., lst Sess. 60 (1977), reprinted in [1977] U.S. CODE CONG. \& AD. NEws 1077, 1138: "This provision authorizes the issuance of a DCO . . . for the purpose of encouraging use of innovative continuous emission reduction technology or process." See also S. Rep. No. 127, 95th Cong., 1st Sess. 47 (1977).

93. H.R. ReP. No. 294, 95th Cong., 1st Sess. 60 (1977), reprinted in [1977] U.S. CODE CONG. \& AD. NEws 1077, 1138. 
The second condition follows naturally from the purpose of the provision: If adequate incentives to employ new methods already exist, there is no need to allow a delay. Yet this condition may prove difficult to apply. Discerning whether a discharger requires a fiveyear extension to experiment with new technology involves a heavy dose of speculation.

The third condition also follows from the statutory purpose: Congress sought to encourage technology superior to "presently available means."94 Unfortunately, section 113(d)(4)(c) does not use this terminology; rather it states that the new technology must be better than what otherwise "would be required." The provision apparently assumes that present plans mandate the best available technology, but that is not necessarily so. If existing technology is capable of exceeding current standards, the statute would appear to permit an extension to develop new controls no better than those currently available. Luckily, the statute's use of the discretionary "may," coupled with the legislative history, should permit the Agency to insist on a promise of bettering existing technology, but the provision is yet another example of loose drafting.

The final condition makes perfect sense; a source should not receive an extension if it practicably can meet present standards while the new equipment is being installed. In determining what is "practicable," the Administrator should bear in mind that interim control facilities are to be replaced in a few years by the fruits of section 113(d)(4) technological innovation; it would defeat the purpose of the innovation to deny an extension because conventional controls would be practicable as a long-term alternative. ${ }^{95}$

Two final aspects of section 113(d)(4) merit attention. The provision does not authorize a blanket five-year extension, but requires that the new technology be applied "as expeditiously as practicable." Thus, while extra time is afforded, it is not a flat reward for committing resources to development; the provision grants only the extra time needed to employ new technology. Of course, practicability in this context should include an opportunity to develop the technology

94. Id. at 61, reprinted in [1977] U.S. CODE CONG. \& AD. NEws 1077, 1139. Congress also sought to encourage development of present technology at significantly lower cost, energy use, or nonair environmental impact. Id.

95. The House Report's example is illustrative: Afterburners might assure interim compliance with hydrocarbon standards, but their use "could result in duplicative and perhaps prohibitive capital expenditures for presently available and new technology, the use of scarce natural gas, and the prospect of interim compliance problems in certain areas due to limited supplies of natural gas," H.R. REP. No. 294, 95th Cong., 1st Śess. 61 (1977), reprinted in [1977] U.S. CODE CONG. \& AD. NEWS 1077, 1139. 
further, if we are not in effect to reinstate the rejected House requirement that the technology be demonstrated before the extension is given. Finally, the statute places the risk that the innovation will not work squarely on the operator, for a section 113(d)(4) order must require compliance within five years, regardless of success. In short, while the policy behind section 113(d)(4) is admirable, Congress's understandable caution in avoiding abuses may significantly dampen the enthusiasm of those intended to be lured by the carrot of delayed compliance.

\section{Coal Conversion}

Prompted by the oil crisis of 1973, Congress in 1974 authorized postponement of plan deadlines applicable to fuel-burning sources under circumstances prescribed in considerable detail.96 Section 113(d)(5), adopted in 1977, replaces and extends this section. The new provision authorizes the Administrator to postpone until December 31, 1980, with possible renewal for another five years, any plan requirement applicable to a "major stationary source . . . burning petroleum products or natural gas" that has been forced to convert to coal either by order of the Federal Energy Administration or because of a government-approved curtailment of natural-gas supplies. The order, however, must contain interim requirements to assure that emissions from the source "will not cause or contribute to concentrations . . . in excess of any national primary ambient air quality standard," and violation of such standards anywhere in the Air Quality Control Region creates a rebuttable presumption against issuing the order. ${ }^{97}$

Not so long ago, industries planned conversion from coal to cleaner fuels to reduce particulate and sulfur-oxide emissions.98 Since then, however, conversion back to coal has become a congressional policy external to the Clean Air Act.99 An operator forced to turn to coal may encounter extreme and blameless hardship, for it may take longer to build control equipment for coal's emissions than to accomplish the fuel switch itself. ${ }^{100}$

Of course, a source in such a position might be "unable to com-

96. See Energy Supply and Environmental Coordination Act of 1974, Pub. L. No. 93-319, sec. 3, \& 119, 88 Stat. 246 (1974) (repealed 1977).

97. 42 U.S.C. $\$ 7413(d)(5)$ (Supp. I 1977).

98. See, e.g., A.E. Staley Mfg. Co. v. Environmental Protection Agency, 2 Ill. P.C.B. 521 (1971).

99. See 15 U.S.C. \$792(a) (1976).

100. The most obvious example is a plant already equipped to burn either coal or gas, but without pollution controls. 
ply" with plan requirements and thus qualify for relief under the general provisions of section 113(d)(1). However, the 1979 deadline for pre-1976 plan requirements in section 113(d)(1) was plainly too strict for coal conversions, especially since the FEA might issue coalconversion orders after 1979. Indeed, it might issue such orders after the 1985 deadline in the conversion provision itself; if that happens, Congress will have to change the statute once more. ${ }^{101}$ The provision exemplifies a principle manifested throughout the 1977 Amendments: the price of temporary provisions is continued legislative tinkering.

Curiously, the coal-conversion situation, which might appear to offer the most compelling case for delayed compliance, is the only instance under section 113(d) in which no extension may postpone compliance with a primary air-quality standard. The notion that hardship should not compromise public health is of course appealing, but the other paragraphs of section 113(d) apparently concede that absolute health protection sometimes carries an unacceptable cost.

Perhaps Congress believed that if a source failed to obtain a conversion extension, the FEA order necessitating conversion would be modified accordingly. After all, requiring shutdown of an electric plant facing a conversion order could impose catastrophic hardships on the community. Nevertheless, the statute does require the order to be modified.

It is also striking that coal-conversion extensions are the only section 113(d) extensions that may be issued only by the Administrator and not by a state. Possibly the great potential for harm stemming from such extensions (limited as they are to "major" sources) induced Congress to keep them under federal control, but extensions under the other paragraphs possess similar potential. Habit more likely explains the greater strictures on coal orders: Congress imposed the primary-standard requirement and excluded state orders in the 1974 coal-conversion provision. On the other hand, the states remain free under section 116 to impose more stringent requirements that may frustrate the federal policy of requiring conversion without unreasonable cost.

Finally, section 113(d)(5) does not seem to cover all cases of undue hardship resulting from coal. conversion. The 1974 statute extended relief to certain operators who had in fact moved to coal

101. The temporary nature of the provision is further underscored by the requirement that, to qualify for a conversion extension because of curtailment in gas supply, a source must have given notice by August 8, 1978. 
without being required to. The new law, in contrast, refrains from encouraging conversions that are not coerced, provides no relief if gas has become too expensive, and gives no quarter to those whose oil supplies have disappeared or become unreliable.

In short, the complex yet incomplete provisions for coal conversion are but another illustration of Congress's insistence on prescribing administrative details rather than enacting a general authorization for relief from unreasonable hardship. Unfortunately, as we move beyond section 113(d) into the other sections of the 1977 Amendments, we will find many other examples.

\section{SMElters AND EMERGENCIES}

\section{A. Smelter Orders}

Primary nonferrous smelters may qualify for delayed-compliance orders under the provisions of section 113(d). In the alternative, they may obtain relief under the new section 119,102 but no smelter "may receive both an enforcement order under [section $113(\mathrm{~d})]$. . . and a primary nonferrous smelter order" under section $119 .{ }^{103}$

Primary nonferrous smelter orders provide relief where "no means of emission limitation" to meet a sulfur-oxide standard "necessary and intended to be of itself sufficient" to achieve primary and secondary ambient standards "has been adequately demonstrated to be reasonably available," considering all costs. ${ }^{104}$ Only smelters that existed when Congress adopted the 1977 Amendments qualify. An initial order may extend compliance until January 1, 1983; a second and final one to January 1, 1988. ${ }^{105}$ The source must take interim measures to prevent violation of the air-quality standards, ${ }^{106}$ and those measures must "include continuous emission reduction technology" 107 unless its use "would be so costly as to necessitate perma-

102. See Clean Air Act Amendments of 1977, $\S 119,42$ U.S.C. $\S 7419$ (Supp. I 1977).

103. 42 U.S.C. $\& 7419$ (a)(2)(A) (Supp. I 1977).

104. 42 U.S.C. $\$ 7419$ (b) (Supp. I 1977). The order may be issued either by the Administrator or, with federal approval, by a state. 42 U.S.C. $\$ 7419$ (a)(1) (Supp. I 1977).

105. 42 U.S.C. $\& 7419$ (c) (Supp. I 1977).

106. 42 U.S.C. $\$ 7419$ (d)(1)(A) (Supp. I 1977). This requirement provides a handhold for the EPA's prior practice of making the user of intermittent controls responsible for any ambient violations in the area. See note 114 infra. Referring to this provision, the House Committee expressly said that "Any occurrence of any such standard being exceeded in a designated liability area for such a smelter would be a violation of the applicable implementation plan by the smelter . . . " H.R. REP. No. 294, 95th Cong., Ist Sess. 62 n.6 (1977), reprinted in [1977] U.S. CODE CONG. \& AD. NEwS 1077, 1140.

107. 42 U.S.C. $\$ 7419$ (d)(1)(C) (Supp. I 1977). A smelter already employing continuous controls need not add others unless the Administrator finds them "reasonably available." 42 U.S.C. $§ 7413(d)$ (4) (Supp. I 1977). 
nent or prolonged temporary cessation of operations." 108 The use of "any such interim measures" is conditioned on agreement "to commit reasonable resources to research and development of appropriate emission control technology."109

\section{Interpretation}

Understanding this mouthful requires a bit of background. Most domestic copper is produced from sulfide ores, and the process generates about two tons of sulfur dioxide for each ton of copper. ${ }^{110}$ If this gas is sufficiently concentrated, it can economically be converted into sulfuric acid and sold. ${ }^{111}$

Before the 1977 Amendments, Nevada's implementation plan required Kennecott Copper Corporation to control sulfur-dioxide emissions by means of a relatively inefficient acid plant, and to curtail copper production when adverse atmospheric conditions caused the remaining emissions to violate ambient standards. The EPA had ruled, with judicial approval, ${ }^{12}$ that section 110 generally required "continuous" rather than "intermittent" controls,"13 but it agreed that to require Kennecott to install a more efficient acid plant would be economically unreasonable and thus allowed periodic cutbacks as an interim measure, subject to certain conditions, ${ }^{114}$ which the Ninth Circuit sustained over the company's objections in Kennecott Copper Corp. v. Train. ${ }^{115}$

In 1977 Congress codified in a new section 123 the EPA's requirement that ambient standards be met by continuous controls. In so doing it omitted from that section the recognized exception for cases, such as Kennecott, in which additional continuous controls

108. 42 U.S.C. $\$ 7419$ (d)(2) (Supp. I 1977).

109. 42 U.S.C. $\$ 7419$ (d)(1)(C)(ii) (Supp. I 1977).

110. Kennecott Copper Corp. v. Train, 526 F.2d 1149, 1150 n.3 (9th Cir. 1975), cert. denied, 425 U.S. 935 (1976).

111. See 41 Fed. Reg. 2232 (1976). While traditional scrubbing of the remaining acidplant emissions was considered to have been "demonstrated," its use on smelters was deemed prohibitively expensive. Id.

112. See, e.g., Big River Elec. Corp. v. Environmental Protection Agency, 523 F.2d 16 (6th Cir. 1975).

113. The statute required that an implementation plan contain "emission limitations. . . and such other measures as may be necessary to insure attainment and maintenance of such [air-quality] . . . standard." 42 U.S.C. $\$ 7410(a)(2)(B)$. The EPA construed this to mean that "other measures" could be required only if reasonable "emission limitations" were insufficient, and ruled that intermittent cutbacks were not "emission limitations." For criticism see Currie, supra note 2 , at $375-77$.

114. The Agency insisted that the company employ additional continuous controls as they became reasonably available, required Kennecott to conduct research to speed their availability, and made the Company agree to be responsible for any ambient violations in the area.

115. 526 F.2d 1149 (9th Cir. 1975), cert. denied, 425 U.S. 935 (1976). 
were not available at reasonable cost. ${ }^{116}$ Thus the new section 119 was necessary to "confirm . . . the Agency's . . . smelter policy" as upheld in the Kennecott case. ${ }^{117}$

Through the lens of this history, the opaque contours of section 119 begin to assume definition. The apparent contradiction between section 119 (d)(1)(A)'s requirement that air-quality standards be met and section 119(b)(3)'s prerequisite that "no means of emission limitation" be "reasonably available" to meet them is explained by the distinction between continuous and intermittent techniques. A smelter qualifies for relief from section 123's ban on intermittent measures if, as in Kennecott, it cannot reasonably achieve ambient standards by continuous "emission limitation" devices such as acid plants alone. Absent unusual circumstances, however, some continuous "reasonably available control technology" will still be required even though it is insufficient to meet present standards; 118 furthermore, although the Conference Committee badly butchered the relevant language, ${ }^{119}$ the new section 119 requires, as approved in Kennecott, a commitment to develop better continuous control technology. ${ }^{120}$

Congress could have accomplished the same result in a more decipherable manner by codifying both halves of the Kennecott doctrine in one section: "Ambient standards must be achieved by

116. 42 U.S.C. § 7423 (Supp. I 1977).

117. H.R. REP. No. 294, 95th Cong., 1st Sess. 61 (1977), reprinted in [1977] U.S. CoDE CONG. \& AD. NEwS 1077, 1139.

118. As the EPA said in an explanatory document quoted with approval by the House Committee, "RACT [reasonably available control technology] will usually equate to control of all strong gas streams [through] properly operated and maintained double contact acid plants (or single contact acid plants where ... already on line)," 41 Fed. Reg. 7450, 7452 (1976). Intermittent cutbacks or high stacks will be allowed as supplementary measures when the acid plant alone is not enough to meet ambient standards.

119. See H.R. Rep. No. 564, 95th Cong., 1st Sess. 63 (1977), reprinted in [1977] U.S. CodE CoNG \& AD. News 1077, 1141.

120. For the Kennecott requirement, see note 114 supra. The House bill provided flatly that the smelter operator "shall" commit development resources, H.R. REP. No. 294, 95th Cong., Ist Sess. 371 (1977). It would also have conditioned the "use of any such interim measures" upon the smelter's acceptance of means to "maximize the reliability and enforceability of such interim measures" and upon agreenent to accept responsibility for any local ambient violations without proof of causation. Id. at 370-71. As adopted, the statute omitted the strict liability provision for local ambient violations, substituting development funds as another condition of "such interim measures." The antecedent for "such" is obscure - in both the House bill and the statute the reference follows the requirement that "such interim measures include "continuous emission reduction technology." Evidently, Congress intended to refer back to permission to use any interim measures, not only the insufficient continuous technology, since the enforceability and causation provisions made sense only in relation to intermittent controls. One conclusion is clear - the phraseology is poor. The statute should have made technology development a condition for gaining permission to deviate from $\S 123$ 's requirement of continuous emission reduction. 
continuous emission reduction unless it is not reasonably available." By separating the two parts, Congress made the statute unnecessarily mysterious. ${ }^{121}$ Furthermore, by limiting the Kennecott qualification to sulfur dioxide emissions from smelters, Congress ran the risk of underinclusiveness: there may be future ambient requirements attainable only through methods outlawed by section 123 . Once again, Congress could have solved the problem adequately and much more simply by drafting a general provision for relief from unreasonable hardship.

\section{Public Hearings}

The hearing provisions of section 119 are as difficult to fathom as its substantive requirements, but not because of unnecessary complexity: with respect to hearings the statute is excessively cryptic. The House bill would have combined smelter orders with other delayed-compliance orders under what became section 113(d) and would have subjected both to a "public hearing" requirement. ${ }^{122}$ As adopted, section 119 contains only a backhanded reference to "any hearing conducted under this section, in the case of an application . . . for a second order."123 It makes no mention of any hearing for the first order, and it does not explicitly require one for the second.

To unravel this mystery, we must follow the bill's path through the Conference Committee. Two things occurred in the Conference. First, the Committee accidentally omitted the explicit hearing requirement from section 119 when it removed smelter orders from section 113(d)'s general provision for delayed compliance. Second, the Committee deliberately limited smelter-order hearings to renew-

121. Splitting the Kennecott doctrine also makes comparison of smelter extensions with \& 113(d)'s extension provisions more difficult. However, understanding the distinct purposes of the smelter provisions and the general DCO provision clears most of the bramble. For instance, $\S 119$, unlike $\S 113(d)$, does not authorize postponement of compliance with either primary or secondary ambient standards. This distinction makes sense if the intermittent or dispersive controls sanctioned under $\S 119$ are not unreasonably expensive; if they are, the smelter may receive some relief under general provisions of $\S 113(d)$. On the other hand, \& 119 permits extensions up to nine years longer than \&113(d), since Congress knew the economic barriers to strict smelter compliance were not amenable to quick solution. Nevertheless, Congress's general philosophy of technology-forcing precluded an open-ended extension provision even for smelters: Not intending "to force some smelters to close at the end of 10 years" and not "certain that the necessary means of emission limitation . . . be made reasonably available," the House Committee was nonetheless "unwilling to concede at this point that the necessary development work cannot be completed within that [10 year] period," H.R. REP. No. 294, 95th Cong., Ist Sess. 62 (1977), reprinted in [1977] U.S. CODE CoNG. \& AD. News 1077, 1140. Congress instead chose to leave subsequent amendment, if necessary, as a safety valve. Id.

122. H.R. Rep. No. 294, 95th Cong., 1st Sess. 368-69 (1977).

123. 42 U.S.C. $§ 7419$ (2)(B) (Supp. I 1977). 
als after the initial order. As the Conference Committee explained, "orders may be issued for an initial 5-year extension without public hearings" except in special cases; ${ }^{124}$ but "prior to granting a second order . . . , there must be notice and a public hearing." 125

Unfortunately, the Conference Report does not say why the Committee deleted the hearing requirement for an initial order. By requiring each applicant to establish that it met statutory criteria 126 instead of flatly postponing the continuous-control requirement for all existing smelters, Congress seems to have indicated its recognition that local circumstances - the size of the operation, the height of preexisting stacks, the prevailing weather, the surrounding terrain - may determine whether an acid plant will achieve ambient standards. These adjudicative facts, which seem to warrant a hearing, are no less relevant to initial orders than to renewal.

Evidently, then, it was not these adjudicative facts that prompted Congress to require a renewal hearing. Indeed the hearing is apparently to be a "legislative" one ${ }^{127}$ better suited to determining facts of general applicability, such as the state of developing technology. Congress apparently thought Kennecott resolved the technology issue for initial orders, but that the question should be reexamined at renewal time in 1983.

Thus the critical adjudicative facts are to be determined upon renewal in a legislative hearing, and upon initial application by whatever procedure the EPA may devise. I have argued above that legislative hearings are less than ideal for this purpose, ${ }^{128}$ and a wholly documentary procedure would still more seriously inhibit meaningful public participation. Since Congress agreed that public participation was essential, ${ }^{129}$ it should have required an adjudicatory hearing for both initial and renewal smelter orders, and the EPA should use its discretion to provide one.

124. When the applicant proposes avoiding the use of any continuous controls, a hearing on the record is required. See 42 U.S.C. $\$ 7419$ (d)(2) (Supp. I 1977).

125. H.R. REP. No. 564, 95th Cong., 1st Sess. 138 (1977), reprinted in [1977] U.S. CoDE Cong. \& AD. NEwS 1502, 1519.

126. See 42 U.S.C. $\$ 7419$ (a)(2)(B) (Supp. 1 1977).

127. In the House bill, the "public hearing" requirement applied both to smelter orders and to delayed-compliance orders under what became $\S 113(\mathrm{~d})$, and the accompanying Report explained that a legislative hearing was intended, see H.R. REP. No. 294, 95th Cong., 1st Sess. 358, 368 (1977).

128. See text at notes 76-85 supra. Since the statute gives no right to obtain such an order, H.R. REP. No. 294, 95th Cong., lst Sess. 68 (1977), reprinted in [1977] U.S. CODE CONG. \& AD. NEws 1077,1146 , the Constitution does not require an adjudicatory hearing unless the regulations confer an entitlement. See note 83 supra.

129. See notes 23 \& 76-77 supra and accompanying text. 


\section{B. Emergency Suspensions}

Fuel shortages during "the severe winter of 1977 "130 prompted the House to include a provision - once again separate from section 113(d) - that would have allowed governors to suspend implementation-plan requirements temporarily in the face of a serious "economic or energy emergency."131 The Conference Committee split this provision into two distinct parts, codified in sections $110(f)$ and (g). ${ }^{132}$

Section 110(f), the more significant of the two, regulates "energy" emergencies. "Upon application by the owner or operator of a fuel burning stationary source," a governor "after notice and opportunity for public hearing . . . may petition the President" to determine personally that an emergency exists "of such severity" as to require "a temporary suspension of any part" of a state-adopted implementation plan. ${ }^{133}$ If the President so finds, the governor may suspend for not over four months "any part" of the plan if a suspension will alleviate "high levels of unemployment or loss of necessary energy supplies for residential dwellings." 134 A section 110(f) suspension is not renewable, ${ }^{135}$ and the Administrator may veto it if it does not meet the stipulated criteria. ${ }^{136}$

Within months of its enactment, section 110(f) was invoked. A prolonged coal strike in the winter of 1977-1978 reduced fuel supplies in several states to dangerously low levels. Ohio, followed by six other states, sought and received a presidential declaration of emergency. ${ }^{137}$

The Ohio experience illustrates several weaknesses in the emergency provision. First, although the statute unambiguously requires "opportunity for a public hearing" before the governor seeks presidential action, the President declared the Ohio emergency without benefit of a hearing, instead requiring that one be held within the next seven days. ${ }^{138}$ Later the EPA feebly explained that, while this

130. See H.R. REP. No. 294, 95th Cong., 1st Sess. 202 (1977), reprinted in [1977] U.S. CoDE Cong \& AD. NEws 1077, 1281.

131. See id. at 354. 1977).

132. Clean Air Act Amendments of 1977, $\S \S 110(\mathrm{f})$, (g), 42 U.S.C. $\S \S 7410(\mathrm{f})$, (g) (Supp. I

133. 42 U.S.C. $\$ 7410(f)(1)$ (Supp. I 1977).

134. 42 U.S.C. \& 7410(f)(1)-(3) (Supp. I 1977). The President may issue such an order for a federally adopted plan. 42 U.S.C. \& $7410(f)(4)$ (Supp. I 1977).

135. 42 U.S.C. $\$ 7410(f)(2)$ (Supp. I 1977).

136. See 42 U.S.C. $\$ 7410(f)(3)$ (Supp. I 1977).

137. See 8 ENVIR. REP. (BNA) 1579, 1923 (1978).

138. See id. at 1726. 
action "may not have been strictly in accordance with the procedural requirements," it was taken "in light of the need to respond quickly to a crisis." 139 But Congress adopted the hearing requirement to ensure that the public interest in a clean environment weigh heavily in the energy emergency balance, and the failure to respect it was flagrant. Of course, advance hearings are not always practicable in emergencies; but the statute makes no accommodation for that situation. If Congress, upon reflection, is unhappy with the balance that the statute strikes, it should amend.

Second, although the President's declaration purported to authorize suspension only of particulate regulations, Ohio suspended sulfur-oxide regulations as well. ${ }^{140}$ The statute's phrasing superficially favors Ohio's interpretation: If the President finds suspension of "any part" of the plan necessary, the state may suspend "any part" of the plan if to do so will alleviate hardship. Ohio's conclusion is not unavoidable, however, for by repeating the term "any part" Congress may have intended to allow the state to suspend only what the President thought required suspending. Although an EPA official opined that Ohio's action "seemed" legal, ${ }^{141}$ the President's interpretation more readily corresponds with the congressional insistence on presidential control of suspensions. ${ }^{142}$ This problem stems from the needlessly complex institutional structure of section 110(f), which goes overboard by requiring the governor, the President, and the EPA all to concur in a decision that must be made swiftly.

The President also limited the declaration to thirty days, ${ }^{143}$ and then renewed it for another thirty. ${ }^{144}$ These dispositions pose two problems. First, the statute flatly prohibits renewal of suspensions: "Not more than one such suspension may be issued for any source on the basis of the same set of circumstances or . . . the same emergency." 145 On the other hand, the statute mandates that a suspension is to be effective "for a maximum of four months or such lesser period as may be specified in a disapproval order of the Administra-

139. Id. at 1727 .

140. See id. at 1579.

141. Id.

142. The statute preserves ultimate federal control through the EPA's power to veto the suspension if it will not help to alleviate the emergency, but Congress thought that authority insufficient; the President's prior determination that relaxation of standards may be necessary is an independent requirement.

143. See 8 ENVIR. REP., supra note 137, at 1579.

144. See id. at 1780 .

145. 42 U.S.C. $\& 7410(f)(2)$ (Supp. I 1977). 
tor." 146 Since the governor is supposed to issue the suspension, it would seem that the governor, and not the President, determines the duration of the relief within the four-month maximum. Thus, it may be that the President had no power to limit the state's initial authority to thirty days, and that his later renewal of the suspension was not only illegal, but also unnecessary.

On the other hand, allowing the President to determine the duration as well as the existence of the emergency fits more compatibly with the congressional policy of presidential control. The President has power to define the geographical scope of the emergency, for he may determine that either a "national" or a "regional" emergency exists, and only governors of states "covered by the President's determination" may issue suspensions. ${ }^{147}$ The statute likewise requires a presidential finding that "temporary" suspension may be necessary to deal with the emergency. ${ }^{148}$ This provision arguably empowers the President to define the duration of the emergency, and indicates that the four-month limitation is an additional safeguard, not a license for governors to give longer relief than the President thinks necessary. ${ }^{149}$

If the President is to be bothered personally with determining whether an emergency exists, he should be given clear authority to define the emergency in all respects, including its duration. Moreover, since there is no reason to believe that energy emergencies will last only four months, Congress's limitation in section 110(f) seems artificial. The renewable thirty-day suspensions authorized in the Ohio case were a much more responsible, flexible course than the nonrenewable four-month suspension apparently contemplated by the statute.

The basic policy of section $110(f)$ is beyond criticism, for it may sometimes be better to violate even primary ambient standards than to allow widespread loss of jobs or of residential heating. President Carter, however, sounded an appropriate word of caution in declaring an emergency in Kentucky: Suspensions should be granted

146. 42 U.S.C. $\S 7410(f)(3)$ (Supp. I 1977).

147. 42 U.S.C. \& 7410(f)(1) (Supp. I 1977). Similarly, I have argued above that the President may determine the pollutants for which controls may be relaxed. See text at notes 140-42 supra.

148. 42 U.S.C. § 7410(f)(1)(A) (Supp. I 1977).

149. The ban on renewal orders applies only to the "suspension . . . issued to a source," not to the President's emergency declaration. However, in Ohio's case this distinction would have made no difference since the Governor quite properly had not attempted to grant suspensions of greater duration than the emergency that had been declared. See 8 ENvir. REP., supra note 137 , at 1579 . 
"sparingly and as a last resort," since turning off a precipitator might save only a small amount of energy yet create a substantial health risk. ${ }^{150}$ Section 110(f), like most of the variance provisions of the Clean Air Act, does not require a determination that the costs of compliance exceed the benefits.

In short, like all the other variance provisions, section $110(f)$ is too restrictive in some respects, too lax in others, and too detailed to be free from serious ambiguities and drafting errors. Energy emergencies, like the other special problems for which complicated variance provisions were scattered almost randomly throughout the Act, could have been handled more rationally by a general provision allowing variance for unreasonable hardship.

Section $110(\mathrm{~g})$, the second emergency provision, was reduced to minor significance by the Conference Committee. The governor, without prior federal approval but subject to subsequent EPA reversal, may temporarily suspend a plan requirement for up to four months 151 when necessary "to prevent the closing for one year or more of any source" resulting in "substantial increases in unemployment."152 As in section $110(\mathrm{f})$, the provision does not require that the unemployment be unreasonable in comparison with the benefits of compliance. But the kicker is that section $110(\mathrm{~g})$ applies only when the state has submitted a proposed plan revision that "meets the requirements of this section" and the EPA has failed to pass upon the revision within the period prescribed by the statute. ${ }^{153}$ Since "the requirements of this section" include assurance that ambient standards will not be violated, ${ }^{154}$ section $110(\mathrm{~g})$ amounts only to transforming the EPA's agreement with the state determination from a condition precedent into a condition subsequent during an economic emergency.

\section{Nonattainment Areas}

\section{A. Background}

The attentive reader may have observed that the bewildering array of special relief provisions in sections $113(\mathrm{~d}), 119$, and 110(f) and (g) does essentially nothing for poor Los Angeles, which we left fac-

150. Id. at 1648 .

151. 42 U.S.C. $\$ 7410$ (g)(2) (Supp. I 1977).

152. 42 U.S.C. $\$ 7410(\mathrm{~g})(1)(B)$ (Supp. I 1977).

153. 42 U.S.C. $\$ 7410(\mathrm{~g})(1)(\mathrm{A})$ (Supp. I 1977).

154. See 42 U.S.C. $\$ \S 7410(a)(2)(A),(a)(3)(B)$ (Supp. 1 1977). 
ing an eighty percent arterial blockage in the summer of $1977 . .^{155}$ Moreover, Los Angeles was by no means alone.

The basic requirement of the 1970 Act, it will be remembered, was that primary ambient standards be achieved no later than five years after plan approval, which for the initial standards meant 1977 . In 1975, however, the EPA reported to Congress that "[o]f the 247 air quality control regions in the Nation, 60 are projected not to meet standards by statutory deadlines" with respect to particulates, and many would fail to meet other standards as well. ${ }^{156}$ If the deadlines had been strictly enforced, existing sources in those regions would have been shut down, with seriously disruptive effects. Moreover, construction of new sources in a noncomplying region seemed to be precluded altogether, since new emissions would contribute to continuing violations of the primary standard. 157

Agreeing that section 110 could not be read "to allow a major new source to make an existing primary NAAQS violation worse"158 but unwilling to abort all new sources, the EPA adopted an "offset" or "tradeoff" policy. A major new source would be permitted in an area not meeting an ambient standard if, among other things, its emissions of the offending pollutant were offset by reductions of existing emissions sufficient to produce "a positive net air quality benefit in the affected area." 159 Since this policy could not prevent the shutdown of existing sources in places like Los Angeles, the EPA also sought from Congress the power to extend plan deadlines "where transportation measures are necessary for the attainment of ... [ambient] standards, and where the implementation of such control measures would have serious adverse social or economic effects." 160 The offset policy and the EPA's legislative proposal were the raw materials from which the Conference Committee produced Part D of the 1977 Amendments, "Plan Requirements for Nonat-

155. See text at note 7 supra.

156. See H.R. REP. No. 294, 95th Cong., 1st Sess. 207-08 (1977), reprinted in U.S. CODE CONG. \& AD. NEws 1077, 1286 (reprinting letter from EPA Administrator Russell Train to Senator Edmund Muskie, May 12, 1975).

157. See id. at 210 , reprinted in U.S. CODE CONG. \& AD. NEws 1077, 1289. Using similar reasoning, the Illinois Pollution Control Board held that new connections to a municipal sewage treatment facility not meeting effluent standards would violate those standards themselves. League of Women Voters v. North Shore San. Dist., I Ill. P.C.B. 369, 384-85 (1971).

158. 41 Fed. Reg. 55527 (1976).

159. 41 Fed. Reg. 55528-29 (1976). The Illinois Board adopted a similar offset policy by allowing new connections to overloaded sewers as long as they were offset by corresponding reductions elsewhere. Currie, supra note 89 , at 422.

160. See 4 ENvir. REP. (BNA) 2004 (1974); Currie, supra note 2, at 389-90. 
tainment Areas"161 - those Air Quality Control Regions, or portions of regions, in which "any national ambient air quality standard" is not met. ${ }^{162}$

The heart of the new provisions is section 172 , which effectively authorizes postponing the date for compliance with primary standards until 1982 or, in the case of oxidants or carbon monoxide, until 1987 , if that is "as expeditiously as practicable."163 Subject to specified conditions, a new state plan may both relax requirements applicable to existing sources and allow the construction of new sources. The nonattainment provisions are a major concession to reality. ${ }^{164}$

The statute, however, goes about all this in a curiously roundabout way. First, it nowhere states explicitly that the Administrator may approve a plan not meeting the three-year deadline of section $110(\mathrm{a})(2)(\mathrm{A}){ }^{165}$ Further, in contrast to the provisions governing promulgation of initial plans, ${ }^{166}$ the new statute does not necessarily authorize the Administrator to prescribe an appropriate nonattainment-area plan if the state fails to do so. ${ }^{167}$ Instead, it relies princi-

161. For a detailed explication of the new requirements, see Raftle, Prevention of Significant Deterioration and Nonattainment Under the Clean Air Act - A Comprehensive Review, EnviR. REP. (BNA) Monograph No. 27 (1979).

162. Clean Air Act Amendments of 1977, § 171(2), 42 U.S.C. § 7501(2) (Supp. I 1977), referring to $\$ 107(d)(1)(A)-(c), 42$ U.S.C. \& 7407(d)(I)(A)-(c) (Supp. I 1977). "Attainment" areas, those in which "any" ambient standard is not shown to be violated, are subject to distinct statutory requirements designed to prevent "significant deterioration." 42 U.S.C., $\$ \S 7471$, $7407(d)(1)(D)$, (E) (Supp. I 1977). The same area may thus be classified as an attainment area for one pollutant and as a nonattainment area for another.

163. 42 U.S.C. $\$ 7502(a)(2)$ (Supp. I 1977). The EPA's offset regulations were to remain in force until mid-1979, Clean Air Act Amendments of 1977, § 129(a). See H.R. Rep. No. 564, 95th Cong., 1st Sess. 157 (1977), reprinted in [1977] U.S. CODE CoNG. \& AD. NEws 1502, 1538. For the EPA's interpretation of the new requirements, see 44 Fed. Reg. 20372 (1979) (to be codified in 40 C.F.R. \$ 52). An earlier memorandum on the subject is located at 8 ENVIR. REP. (BNA) 1714 (1978). The agency's revised offset policy, which governs in the interim, may be found in 44 Fed. Reg. 3282 (1979) (to be codified in 40 C.F.R. $\$$ 51, App. S).

164. Interim relief for communities like Los Angeles was provided by a new $\$ 110(c)(4), 42$ U.S.C. \$ 7410(c)(4) (Supp. I 1977), which authorized a governor, "after notice and opportunity for public hearing," to suspend certain transportation control requirements pending submission of a nonattainment plan. The provisions subject to suspension were those requiring retrofit of noncommercial vehicles, reduction of on-street parking, and "gas rationing which the Administrator finds would have seriously disruptive and widespread economic or social effects." The suspension was to last only until January 1, 1979, or until the state submitted its revision, "whichever is earlier." However, the revision is ineffective until approved by the EPA; between its submission and approval there may be widespread violations. The Agency will presumably overlook them, but the matter should not have been left to the Administrator's discretion.

165. That the extension is approvable is implicit; otherwise the entire nonattainment provision would be of no effect.

166. 42 U.S.C. $\$ \$ 7410(a)(1)$, (c)(1) (Supp. I 1977).

167. The statute authorizes federal revision only when ambient standards are altered or the Administrator finds an existing plan inadequate. 42 U.S.C. $\$ \$ 7410(a)(2)(H)(i i),(c)(1)(C)$ (Supp. I 1977). Yet the nonattainment provisions apply wherever ambient standards are vio- 
pally on blackmail: Any state failing to adopt a satisfactory nonattainment plan by mid-1979 faced not only a ban on the construction of new major stationary sources contributing to ambient violations, ${ }^{168}$ but the loss of federal funds for construction of highways ${ }^{169}$ and sewage-treatment facilities as well. ${ }^{170}$

Economic necessities would doubtless have brought about de facto relaxations of the deadlines even if the statute had not been amended. What Congress was trying to coerce was rather the adoption of the accompanying provisions for assuring compliance as soon as practicable. Even so, the means seem ill-suited to the end. Congress could better have assured the desired revisions by requiring the EPA to make them if the states defaulted. Moreover, it seems both unfair to innocent owners of new sources and contrary to the federal nonattainment policy that the remedy for state inaction is to forbid new construction altogether. ${ }^{171}$

Nevertheless, despite some delays, the states are falling into line; 172 nonattainment plans will in all likelihood soon be universal.

lated, including any areas in which the existing plan, while not being enforced, is facially adequate.

168. Section $110(a)(2)(1)$ requires that a plan forbid construction or modification of such a source after June 30,1979 , unless at the time a permit is sought "such plan meets the requirements of part D." 42 U.S.C. $\$ 7410$ (a)(2)(I) (Supp. I 1977). Section 172 provides in turn that a plan satisfying $\S 110(a)(2)(I)$ must assure attainment of ambient standards by the appropriate 1982 or 1987 deadlines. 42 U.S.C. $\$ 7502$ (Supp. I 1977).

169. 42 U.S.C. $\$ 7506$ (a) (Supp. I 1977). This prohibition applies only to states failing to adopt plans for transportation sources.

170. 42 U.S.C. $\$ 7616(b)$ (2) (Supp. I 1977). The authority to withhold sewage funds is discretionary.

171. Moreover, the EPA has warned that broad application of the provisions for cutting off federal grants could have "disastrous effects." 9 ENVIR. REP. (BNA) 1351 (1978).

172. Section 406(d) of the 1977 Amendments, Pub. L. No. 95-95, 91 Stat. 795, as amended Pub. L. No. 95-190 § 14(b)(6), 91 Stat. 1405 (not codified in 42 U.S.C.), imposed a deadline of August 7, 1978, or nine months after adoption of implementing regulations, whichever was later, for submission of revised plans "required" by the amendments. See 42 U.S.C.A. $§ 7401$ note (West 1978). The EPA translated the nine-month requirement into a January 1,1979 deadline. See 44 Fed. Reg. 20372, 20373 (1979). Only seven states met those deadlines. See 9 ENVIR. REP. (BNA) 1739 (1979). The EPA, however, valuing charity above obedience to the statute, took several steps to reduce hardship. The construction bar was deemed to apply only to permits for which application was made after July 1, 1979, later applications would be processed immediately so that construction could begin as soon as the plan was approved; plans with minor deficiencies would be conditionally approved so that construction could proceed; and funds would be withheld only from states that did not make good-faith efforts to comply. 44 Fed. Reg. 35679 (1979). By November 1979 most states had submitted revised plans, and though the bulk of them had not been approved, the EPA said it expected only "isolated" interference with planned construction. 10 ENVIR. REP. (BNA) 1472-73 (1979).

Transition problems were further complicated by the decisions in United States Steel Corp. v. Environmental Protection Agency, 595 F.2d 207 (5th Cir. 1979), and in Sharon Steel Corp. v. Environmental Protection Agency, 597 F.2d 377 (3d Cir. 1979), setting aside the EPA's designation of nonattainment areas in Alabama and Pennsylvania on the ground that there was insufficient cause for departing from the notice-and-comment procedures of 5 U.S.C. $\S 553(b) \&(c)$ (1976). With more respect for congressional policy than for statutory language, 
The following sections examine the requirements for such plans, first for existing and then for new sources of pollution.

\section{B. Existing Sources}

\section{1982 Requirements}

As far as existing sources are concerned, the basic requirements of a 1982 nonattainment plan are found in the apparently redundant provisions of sections $172(\mathrm{~b})(2)$ and (3): The new plan must "provide for the implementation of all reasonably available control measures as expeditiously as practicable," and it must "require, in the interim, reasonable further progress . . . including such reduction in emissions from existing sources in the area as may be obtained through the adoption, at a minimum, of reasonably available control technology." 173

The Senate Report emphasized that both lead time and "economic or social cost" could be considered in determining what was "reasonably available." 174 Moreover, despite a disclaimer that "this bill does not define reasonable measures,"175 the Report gives specific examples that will doubtless be accorded considerable deference in administering section 172: While "an inspection and maintenance program [for vehicles] is a reasonable measure," gasoline rationing "currently" is not, nor is "retrofitting existing cars with currently available devices." 176 But this provision, reflecting the need it was designed to meet, postpones only the impracticable: Los Angeles need not shut down tomorrow, but it must take all reasonable measures as quickly as it can.

Conspicuously missing from section 172 , however, as from the

the Fifth Circuit added by way of soothing advice that the ban on new construction would not apply until plan revisions were actually adopted in accordance with the nonattainment provisions. Until then, the court decreed, the EPA offset ruling would govern.

173. 42 U.S.C. § 7502(b)(2), (3) (Supp. I 1977).

174. S. REP. No. 127, 95th Cong., 1st Sess. 40 (1977). The same term is employed in connection with smelter orders in $\$ 119$ (c)(1). See text at notes 108-11 supra.

175. S. ReP. No. 127, 95th Cong., Ist Sess. 39-40 (1977).

176. Id. The EPA has proposed to determine what transportation-control measures are "reasonably available" on "a case-by-case basis," with presumption that measures listed in $\S 108(\mathrm{f})(\mathrm{I})(\mathrm{A})$ (as to which the Agency is to publish information) are reasonably available. 44 Fed. Reg. 20372, 20377 (1979) (to be codified in 40 C.F.R. § 52).

To help states achieve ambient standards in nonattainment areas, Congress in $\S 177,42$ U.S.C. $\$ 7507$ (Supp. I 1977), sensibly permitted them to adopt new-vehicle emission standards more stringent than federal standards. Those standards, however, must be identical to the ones adopted by California and approved by the EPA under the existing California exception. This scheme assures that vehicle manufacturers will not be required to produce cars meeting more than present dual standards. See H.R. Rep. No. 294, 95th Cong., Ist Sess. 213, 310-11 (1977), reprinted in [1977] U.S. CODE CONG. \& AD. NewS 1077, 1292, 1389-90. 
delayed-compliance provisions of section 113(d), is any requirement that the present impracticability of compliance with the original deadline not be attributable to the past sluggishness or recalcitrance of the discharger. ${ }^{177}$ The Amendments thus appear to permit a state to grant a polluter additional time because the operator has made timely compliance no longer "reasonable" by sitting on its corporate rump. True, section 172 does not require a state to do so; theoretically, the state may choose not to submit a revised plan. Moreover, the amendments do not disturb Union Electric's holding that a state may submit a plan more stringent than federal law requires. ${ }^{178}$ But as in the case of section 113(d), I do not think that Congress should have granted states the power to insulate dischargers from penalties for inexcusable violations of federal law.

While the requirements of "reasonably available control measures" and "reasonably available control technology" appear essentially duplicative with respect to existing sources, ${ }^{179}$ the provision for "reasonable further progress" 180 goes further. The statute defines "reasonable further progress" as "annual incremental reductions in emissions . . . sufficient . . . to provide for attainment of the . . . ambient . . . standards by the date required"; it calls for "substantial reductions in the early years following approval or promulgation" and "regular reductions thereafter." 181 Thus in this context "reasonable" does not mean at reasonable cost; regular reductions are demanded whether or not practicable, contrary to the sensible policy of accommodation underlying the entire nonattainment provision. ${ }^{182}$ The prospects for achieving "reasonable further progress" in Los Angeles under this standard seem bleak. The development of public transportation, perhaps the city's most promising approach to its

177. See text at notes $39-42$ supra.

178. Union Elec. Co. v. Environmental Protection Agency, 427 U.S. 246 (1976).

179. The requirement that the plan adopt all reasonably available technology "at a minimum," however, seems to anticipate that even unreasonably expensive measures may be required.

180. 42 U.S.C. $\$ 7502(b)(3)$ (Supp. I 1977).

181. 42 U.S.C. \$ 7501(1) (Supp. I 1977). The EPA construes this definition to require a "straight-line rate" of progress determined by "dividing the total emission reductions required . . . by the number of years between 1979 and the date projected for attainment," allowing "some lag" in the early years "if immediate compliance is not possible." See 8 ENVIR. REP. (BNA) 1714, 1715 (1978).

182. The legislative history confirms this interpretation. The House bill would have required reduction of emissions in equal two-year installments. See H.R. REP. No. 294, 95th Cong., lst Sess. 212 (1977), reprinted in [1977] U.S. CODE CONG. \& AD. NEws 1077, 1291. While the Conference Committee thought this requirement too rigid, it stressed that "regular, consistent emission reductions will be demonstrated . . . throughout the period," H.R. REP. No. 564, 95th Cong., 1st Sess. 157 (1977), reprinted in [1977] U.S. CODE CONG. \& AD. NEwS 1502,1538 . 
problem, seems less likely to cause substantially equal incremental reductions in emissions than a dramatic improvement several years hence. Los Angeles may yet have to reduce gasoline sales ten percent a year.

\section{1987 Requirements}

A revised plan must meet the conditions already discussed, along with others applicable to new sources, in order to obtain an extension to 1982, when Congress intended that most ambient standards would be achieved. To qualify for extension of oxidant and carbonmonoxide standards to 1987, a plan must meet additional conditions. Among other things, the plan must identify new measures, not presently feasible, that will be necessary for attainment by 1987 ; it must provide for "a vehicle emission control inspection and maintenance program"; and by 1982 it must be amended to "contain enforceable measures to ensure attainment" by December $21,1987 .{ }^{183}$ The interrelationship of these requirements with that of "reasonable further progress" is not clear. On the one hand, the Conference Report flatly confirms what the 1987 conditions appear to suggest on their face: the state "need not make a commitment in 1979 to implement" measures not "reasonably available." 184 On the other hand, the 1987 provisions do not in terms purport to modify the clear 1982 requirement of "annual incremental reductions" regardless of cost.

The Conference Report also states that, as a further condition for the 1987 extension, a plan "must require that funds reasonably available to the state or local government be used to improve public transportation." 185 The diligent reader, however, will search in vain to find such a provision in section 172, where it belongs: instead, it is hidden in sections $110(a)(3)(D)$ and $110(c)(5)(B)$.

Upon reading the two provisions, one almost wishes that they had remained hidden. Section 110(a)(3)(D) requires any plan revised beyond 1982 under section 172 to include measures specified by section $110(\mathrm{c})(5)(\mathrm{B})$ - specifically, "comprehensive measures ... to . . . establish, expand, or improve public transportation measures to meet basic transportation needs, as expeditiously as practicable."186 While public transportation may be a promising av-

183. 42 U.S.C. $\$ 7502(b)(11)-(c)$ (Supp. I 1977). See H.R. Rep. No. 564, 95th Cong., 1st Sess. 157 (1977), reprinted in [1977] U.S. CODE CoNG. \& AD. News 1502, 1537.

184. H.R. REP. No. 564, 95th Cong., 1st Sess. 157 (1977), reprinted in [1977] U.S. CoDE Cong \& AD. NEws at 1502, 1537.

185. Id.

186. 42 U.S.C. $\$ 7410(a)(3)(D)$, (c)(5)(B) (Supp. I 1977). 
enue for achieving ambient standards in many cities, it seems imprudent for Congress to prescribe that course woodenly without knowing that it will be the most efficient means in every city. San Francisco's meat may well be Los Angeles's poison. Moreover, even if public transportation is the best available means of attaining the standards, Congress has once more failed to acknowledge the possibility that the cost of meeting those standards may be unrealistically high.

\section{General Implications}

In summary, the nonattainment provisions for existing sources commendably recognize that more time may be necessary to avoid unreasonable hardship, and the "expeditiously as practicable" requirement applied to each control measure demands a proper comparison of the costs and benefits of delay. Unfortunately, the provisions are marred on the one side by congressional willingness to allow states to reward past dilatory behavior and on the other by an unrealistic insistence upon annual increments of progress whether or not economically justifiable. Moreover, like all the other variance provisions they fail to acknowledge the possibility that compliance with primary standards may in some circumstances never be worth the cost.

There is an additional problem. The absolute deadlines of 1982 and 1987 demonstrate that the nonattainment provisions were intended not as permanent parts of the statutory scheme but as a temporary response to the supposedly unique problems associated with achieving the initial group of ambient standards. Yet it seems unreasonable to expect that the achievement of other, more stringent standards promulgated in the future will be free from similar difficulties. If they occur, Congress will have to intervene once more, while a general variance provision allowing justifiable extensions, or deletion of the absolute time limits of section 110 , would have saved it the trouble.

\section{New Sources}

\section{The Permit Requirement}

Under section 172(b)(6), a nonattainment-area plan revision must "require permits for the construction and operation of new or modified major stationary sources." 187 The section does not specify

187. 42 U.S.C. $\$ 7502(b)(6)$ (Supp. I 1977). The terms "new" and "modified" have counterparts in $\$ 111$, which provides for standards of performance for "new" stationary sources, 
whether permits are required for sources outside the area but affecting it. One might infer that they are not, since the construction ban to be imposed upon failure to adopt an adequate plan applies only to sources "in any nonattainment area." 188 Control of outside sources, however, is indispensable if the goal of the nonattainment provisions is to be attained. The EPA's offset policy applied to sources outside the noncomplying area, ${ }^{189}$ and the nonattainment sections basically endorsed that policy. Moreover, whether or not the permit requirement of section 172(b)(6) applies to outside sources, the EPA should be able to demand permits from them under the general direction of section 172(a)(i) that the plan provide for timely achievement of ambient standards in nonattainment areas. ${ }^{190}$ Initially the Agency did

defined by $\$ 111(a)(2)$ to include "any stationary source, the construction or modification of which is commenced after the publication of regulations (or, if earlier, proposed regulations) prescribing [an applicable] standard of performance ...." "Modification" in $\$ 111$ in turn means "any physical change in, or change in the method of operation of, a stationary source which increases the amount of any air pollutant emitted." 42 U.S.C. \& 7411(a)(2), (3) (Supp. I 1977). The commencement of construction is not defined in $\S 111$, but the same term is defined for purposes of the provisions for prevention of significant deterioration in $\S 169(2), 42$ U.S.C. $\$ 7479$ (2) (Supp. I 1977). The nonattainment provisions adopt the $\$ 111$ definition of "modification" but do not define "new sources" either explicitly or by reference. Section 171(4), 42 U.S.C. \& 7501(4) (Supp. I 1977). Nevertheless it seems most probable that the § 111 definition will be applied by analogy.

I have discussed the meaning of the $\$ 111$ terms elsewhere, Currie, Direct Federal Regulation of Stationary Sources Under the Clean Air Act, - U. PA. L. REv. -, - (1980) (forthcoming), and shall not repeat the discussion here. Suffice it to say that the problem has proved surprisingly complex. One point, however, deserves mention. After the decision in Alabama Power Co. v. Costle, 606 F.2d 1068, 1082-85 (D.C. Cir. 1979), the EPA proposed to revise its nonattainment-plan regulations to incorporate fully the so-called "bubble" concept, under which there is no "increase in the amount . . . emitted," and thus no permit-triggering "modification," if an increase in emissions from one machine is cancelled by reductions elsewhere in the same plant. See 44 Fed. Reg. 51924, 51933 (1979), reprinted in 10 ENVIR. REP. (BNA) 1112,1121 (1979). However, if no nonattainment plan is in effect to assure "reasonable further progress" toward attaining ambient standards, the individual machine will be considered a "source" and the "bubble" concept will not apply. The EPA correctly feared that otherwise rare opportunities to move toward attainment might be missed. Id. at 51932, 10 ENVIR. REP. (BNA) at 1120.

188. See 42 U.S.C. $\$ 7410$ (a)(2)(I) (Supp. I 1977). The EPA has proposed to construe this provision to apply to sources outside nonattainment areas but affecting them. 44 Fed. Reg. 38583 (1979). The language, however, is to the contrary.

189. See 41 Fed. Reg. 55524, 55526 (1976); 44 Fed. Reg. 3274, 3283 (1979).

190. In the converse situation, the District of Columbia Circuit has held the EPA cannot under provisions for preventing deterioration of attainment areas require permits for sources in nonattainment areas in the same state. Alabama Power Co. v. Costle, 606 F.2d 1068, 1082-85 (D.C. Cir. 1979). I have criticized this decision elsewhere, see Currie, Nondegradation and Vistbility Under the Clean Air Act, 68 CALIF. L. REv. 48 (1980), but the present problem is distinguishable, for the provision construed in Alabama Power expressly required permits only for construction "in any area to which this part applies," meaning an attainment area. 42 U.S.C. $\S 7475$ (a) (Supp. I 1977).

In support of its authority to impose nonattainment requirements on sources in clean areas, the EPA has pointed to $\S 165$ (a)(3)(B) 42 U.S.C. \& 7475(a)(3)(B) (Supp. I 1977), which forbids construction of such a source if it would cause or contribute to pollution "in excess of any . . . national ambient air quality standard in any air quality control region." See 44 Fed. Reg. 51924, 51939 (1979), reprinted in 10 ENVIR. REP. (BNA) 1112, 1127 (1979). But the EPA's 
intend to apply nonattainment requirements to such sources, ${ }^{191}$ but more recently it announced that it was considering changing that policy, suggesting that its former position would be "burdensome to both the permitting authority and the permit applicant."'192

Geographical considerations aside, only a "major" new source need apply for a permit. Nevertheless the statute may reach more sources than it should. Section 302(j) defines a "major stationary source" as one with "potential to emit"193 "one hundred tons per year of any air pollutant." 194 Hence, contrary to the EPA's position, the permit requirement is not limited to sources of those pollutants for which ambient standards have been adopted. 195 Indeed, since "air pollutant" includes "any physical, chemical, biological, radioactive .. . substance," 196 the statute apparently requires the wasteful process of issuing permits for sources emitting nothing more harmful

interpretation would risk outlawing such sources even if all Part D requirements were met, since the new source would "contribute to" the continuing violation. Section 165 can be reconciled with the nonattainment provisions by recognizing that the latter effectively postpone the date when ambient standards apply to the affected areas, so that new emissions do not contribute to pollution "in excess of" any currently applicable standard.

191. 44 Fed. Reg. 20372, 20379 (1979). (1979).

192. 44 Fed. Reg. 51924, 51939 (1979), reprinted in 10 ENVIR. REP. (BNA) at 1112, 1127

193. The D.C. Circuit rejected the EPA's definition of "potential" emissions as those that would occur in the absence of control equipment in the context of the nondegradation provisions in Alabama Power Co. v. Costle, 606 F.2d 1068, 1075-76 (D.C. Cir. 1979). The Agency has acquiesced, proposing to redefine "potential" emissions for both purposes as those expected to result "after the application of air pollution control equipment." See 44 Fed. Reg. 51924,51929 (1979), reprinted in 10 ENVIR. REP. (BNA) at 1112, 1117 (1979). For criticism see Currie, supra note 190, at 53-60.

194. Clean Air Act Amendments of 1977, § 302(j), 42 U.S.C. § 7602(j) (Supp. I 1977).

The permit requirement applies to "major new or modified stationary sources," 42 U.S.C. $\S 7502$ (b)(6) (Supp. I 1977), leaving ambiguous whether a permit is needed when a "major" source undergoes a modification that increases its potential emissions by less than the 100 -ton threshold. Congress's evident purpose to avoid the cost of processing permits in the absence of substantial increases in emissions suggests only "major" modifications should qualify. In the context of permits for "construction" of "major" sources in clean areas, the EPA's effort to limit permits to major modifications was struck down; the relevant provision defines "construction" to include "modification," and the latter includes any changes that "increase" emissions without regard to amount. Alabama Power Co. v. Costle, 606 F.2d 1068, 1068 (D.C. Cir. 1979) (construing 42 U.S.C. $\$ \S 7475(a), 7479(2)(C)$, \& 7411(a)(4) (Supp. I 1977)). The nonattainment provisions, while similar in design, do not contain the same ironclad language. Nevertheless the EPA has proposed to require permits under both provisions for any modification of a major source resulting in a "significant" increase in emissions, whether or not meeting the 100-ton standard. See 44 Fed. Reg. 51924, 51958, 51956, 51952 (1979), reprinted in 10 ENVIR. REP. (BNA) at 1112, 1146, 1144, 1140 (1979).

195. See 44 Fed. Reg. 20372, 20374 (1979), defining "major" sources as in the revised offset ruling, 44 Fed. Reg. 3274, 3283 (1979): "any source for which the potential emission is equal to or greater than 100 tons per year of any of the following pollutants: particulate matter, sulfur oxides, nitrogen oxides, volatile organic compounds, or carbon monoxide." This approach antedated the 1977 Amendments. See 41 Fed. Reg. 55528 (1976).

196. 42 U.S.C. $\$ 7602$ (g) (Supp. I 1977). 
than water. To limit the cure to the disease, Congress should have required permits only for sources of pollutants whose concentrations exceed ambient standards.

Section 173 lists the conditions for permit issuance. ${ }^{197}$ The two most important conditions are discussed in the sections that follow, but two other conditions deserve special mention. First, all "major stationary sources" in the same state that are under the applicant's control must be "in compliance, or on a schedule for compliance, with all applicable emission limitations and standards" under the Clean Air Act. ${ }^{198}$ This requirement should serve as a powerful incentive to an owner to bring other sources into line, but it may also inflict penalties disproportionate to the offense, especially since there is no exception for violations the discharger could not reasonably prevent. ${ }^{199}$ Second, the permit may not be issued unless the entire state implementation plan is "being carried out" as required by law. 200 This requirement is even more severe, for it punishes the new-source applicant for the state's failure to enforce the plan against other dischargers, a matter over which the applicant has no control.

\section{Lowest Achievable Emission Rate}

To obtain a permit, a new source must comply with "the lowest achievable emission rate"201 (LAER). Section 171(3) defines LAER as "the most stringent emission limitation . . . contained in the im-

197. 42 U.S.C. $\$ 7503$ (Supp. I 1977). Comparable permit provisions for new sources in attainment areas and for all sources under the water-pollution statute require opportunity for a "public hearing" before issuance or denial of a permit. 42 U.S.C. \& 7575(a)(2) (Supp. I 1977); 33 U.S.C. \& 1342(a)(1), (b)(3) (1976). The nonattainment provisions, unfortunately, do not. Since the permit requirement applies only to "major" sources, the importance of each application both to the applicant and to the public suggests the desirability of providing a full opportunity for input. Moreover, deciding whether the proposed new source meets the various statutory requirements may often necessitate determinations of facts peculiar to that source, and this consideration militates in favor of an adjudicatory hearing. Indeed, if the plan adopted gives the applicant a right to a permit upon meeting prescribed criteria, due process very likely will require that he be given the opportunity for such a hearing. See note 83 supra.

Moreover, again in contrast to the water-pollution provision, 33 U.S.C. \& 1342(d) (1976), $\$ 173$ does not provide for EPA review to prevent issuance of a permit contravening statutory requirements. If the emissions from the new plant actually contravene provisions of the plan itself, the EPA can sue or issue an order to enforce the requirement, 42 U.S.C. $\S 7413$ (a)(1)-(b) (Supp. I 1977). However, the very basis of the permit requirement is that prevention is preferable to cure.

198. 42 U.S.C. \& 7503(3) (Supp. I 1977).

199. Presumably a discharger meeting the conditions of a DCO or other extension is "on schedule for compliance," but as I pointed out above, a reasonable excuse for inability to comply does not guarantee the issuance of a DCO. See text at notes 66-76 supra.

200. 42 U.S.C. $\$ 7503(4)$ (Supp. I 1977).

201. 42 U.S.C. $\$ 7503(2)$ (Supp. I 1977). 
plementation plan of any State" (unless shown "not achievable") or "the most stringent emission limitation achieved in practice, . . . whichever is more stringent."202 Because LAER may not be less stringent than the standards of performance for new sources under section 111 , it requires use of "the best technological system of continuous emission reduction . . . adequately demonstrated," considering cost. ${ }^{203}$ The House Report explained that, while "cost is of somewhat lesser weight" in determining "lowest achievable emission rate" than under section 111, it remains "a relevant factor": "if the cost of any given . . . means of compliance is so great that new . . . sources could not build and operate, then emission reductions which necessitate [its] use ... would not be considered achievable ...."204

The policy concern underlying this provision is unassailable the law ought to demand special efforts to minimize additional emissions in areas where pollution levels already endanger public health. ${ }^{205}$ The same philosophy prompted the further rule that, if compliance is extended beyond 1982, the agency issuing the permit must analyze "alternative sites, sizes, production processes, and environmental control techniques" and insist upon a showing that "benefits of the proposed source significantly outweigh the environmental and social costs" of its operation. ${ }^{206}$ Indeed, the latter requirement more accurately reflects the relevant policies than does the "lowest achievable" provision: The post-1982 requirement explicitly requires that the benefits of the new source be balanced against the health risk, while the "lowest achievable" provision conclusively presumes that the benefits are sufficient if the owner is willing to install expensive technology.

202. 42 U.S.C. § 7501(3) (Supp. I 1977).

203. 42 U.S.C. $\$ 7411(a)(1)$ (Supp. I 1977).

204. H.R. REP. No. 294, 95th Cong., Ist Sess. 215 (1977), reprinted in [1977] U.S. CoDE CoNG \& AD. News 1077, 1294. The Conference Report is in accord. H.R. REP. No. 564, 95th Cong., Ist Sess. 157 (1977), reprinted in [1977] U.S. CODE CONG. \&-AD. News 1502, 1538. The determination of LAER is to be made by the agency issuing the permit, 42 U.S.C. \& 7503(2) (Supp. I 1977), but for an entire "class or category of source," 42 U.S.C. § 7501(3) (Supp. I 1977), and with the assistance of "guidance documents" issued by the EPA, 42 U.S.C. $\$ 7508$ (Supp. I 1977). Contrast 42 U.S.C. \& 7479(3) (Supp. I 1977), which for purposes of preventing significant deterioration of attainment areas requires the determination of best available control technology to be made "on a case-by-case basis," seeking marginal additional control at additional administrative cost.

205. See H.R. REP. No. 294, 95th Cong., 1st Sess. 214-15 (1977), reprinted in [1977] U.S. CODE CONG. \& AD. News 1077, 1293-94. Whether in light of the independent offset requirement considered at notes $210-28$ infra the benefits of requiring technology beyond that prescribed under $\$ 111$ justify the administrative burdens of multiple new-source standards, I am not certain. See generally Currie, supra note 190.

206. 42 U.S.C. $\& 7502(b)(11)(A)$ (Supp. I 1977). 
Unfortunately, the statute does not say whether LAER is necessary for every pollutant emitted by a major source. The EPA has concluded that it is not, and its position seems correct. To begin with, LAER is a means for achieving the purpose of the nonattainment provisions, which is to minimize existing violations of ambient standards. ${ }^{207}$ This purpose demands LAER only for those pollutants whose concentrations exceed ambient standards. Moreover, the statutory limitation of LAER to "major" sources 208 suggests Congress thought the benefits of such technology not worth the cost of requiring it unless the amount emitted was substantial. The fortuity that a source is "major" for one pollutant seems no reason to alter that policy with respect to other pollutants for which the source is not major. Accordingly, the EPA position is that LAER is required only for those pollutants whose ambient standards are violated and for which at the same time the source is "major."209

\section{Offset and Its Alternative}

As a final condition for obtaining a permit, a new source in a nonattainment area must show that it either conforms to a modified version of the pre-1977 EPA offset policy or contains alternative provisions adequate to assure that new sources do not impede overall progress toward timely attainment of ambient standards.

\section{a. The Offset Requirement}

Under this alternative, the reduction of existing emissions may make room for new ones. The wording of section 173(1)(A) is tricky: The new source is allowed only if "total allowable emissions" from existing and new sources are "sufficiently less than total emissions from existing sources allowed under the applicable implementation plan" at the time the permit is sought "so as to represent . . . reasonable progress." 210 Notice that the statute requires that new emissions

207. This purpose is exemplified by the definition of "reasonable further progress" in $\S 171(1), 42$ U.S.C. $\$ 7501$ (1) (Supp. I 1977), and by the central requirement of $\S 172$ (a) that ambient standards be achieved by 1982 or 1987. 42 U.S.C. $\$ 7502$ (a)(1) (Supp. I 1977).

208. 42 U.S.C. $\$ \S 7502(b)(6), 7503(2)(S u p p$. I 1977).

209. See 44 Fed. Reg. 51924, 51959 (1979), proposing 40 C.F.R. $\$ 51.18(j)(3)$, reprinted in 10 ENVIR. REP. (BNA) at 1112, 1147 (1979); id. at 51941, 10 ENVIR. REP. at 1129, for a partial interpretation of the proposal. The pre-1977 offset policy had also required the administrative equivalent of LAER only "for those pollutants causing the proposed source to be defined as a 'major' source," 41 Fed. Reg. 55528 n.2 (1976). The corresponding provision for clean areas in $\S 165$ (a)(4), by contrast, requires best available technology for "each pollutant subject to regulation under this chapter," whether or not subject to ambient standards and whether or not ambient standards are met. 42 U.S.C. § 7475(a)(4) (Supp. I 1977).

210. 42 U.S.C. $\$ 7503(1)$ (A) (Supp. I 1977). The language is taken largely from the Senate bill, see S. REP. No. 127, 95th Cong., 1st Sess. 146 (1977). 
be more than offset: "total allowable emissions" of the offending pollutant ${ }^{211}$ must actually be reduced despite the addition of the new source. Thus Congress viewed the addition of a new source as an opportunity to create additional incentives to correct existing problems. The reference to "emissions allowed under the ... plan"212 ensures that the new-source owner will implement emission reductions that were not already overdue ${ }^{213}$ - the statute gives no credit for abatement that should have been accomplished in the past. ${ }^{214}$ The amount of the required reduction will vary according to the extent of the ambient violation and the efficacy of other plan measures required by the nonattainment provisions to make "reasonable further progress" toward ambient standards. The necessary reductions must take place "by the time the [new] source is to commence operation."215

Under the pre-amendment offset policy, the EPA's guidelines had explicitly required not only that emission reductions exceed new emissions, but also that these reductions "provide a positive net air quality benefit in the affected area."216 This latter requirement recognized that emissions of identical quantity and concentration may have disparate effects on ambient quality, depending on their locations, their altitudes, and their timing. Section 173(1)(A) preserved the essence of the "net air quality benefit" requirement by demanding offset reductions "sufficient[] ... to represent ... [with other reductions] reasonable further progress" toward timely attainment of

211. The statute speaks flatly of "total allowable emissions," but the context strongly suggests the sole concern is with those pollutants whose concentration exceeds ambient standards. See text at note 209 supra.

212. The use of "allowable" rather than actual emissions as the basis for post-construction assessment is a necessary corollary to avoid penalizing the new source for continuing violations of the implementation plan by other sources.

213. Pressing this principle further, the EPA before 1977 had also refused to allow credit for some reductions not required by existing plans. If the plan faced revision due to nonattainment of air-quality standards, credit was allowed only for reductions beyond those resulting from "reasonably available control measures." See 41 Fed. Reg. 55526 (1976). Since the statutory offset policy applies only after approval of a plan requiring reasonably available control measures, the result should be the same under the statute, although the Conference Committee declared that before the approval of new plans the baseline for applying the offset policy should be the plan in effect at the time of permit application, regardless of its inadequacy. H.R. REP. No. 564, 95th Cong., Ist Sess. 157 (1977), reprinted in [1977] U.S. CoDE CoNG \& AD. NEWS 1502, 1538.

214. The statutory reference to "allowable emissions" seems also to preserve the EPA's requirement that offset reductions be "enforceable," that is, that they be made part of the plan itself or written into a permit or compliance order. 41 Fed. Reg. 55530 (1976).

215. 42 U.S.C. \& 7503(1)(A) (Supp. I 1977).

216. 41 Fed. Reg. 55529 (1976). The revised interim offset policy preserved this basic requirement. 44 Fed. Reg. 3284 (1979). 
ambient standards. ${ }^{217}$

What is not so clear, however, is whether the statute modifies the EPA's requirement that this air-quality benefit occur "in the affected area."218 A narrow definition of "affected area" could have limited the applicability of offset to reductions immediately adjacent to the new source. ${ }^{219}$ Section 173, however, refers to a net reduction of emissions "in the region," 220 and in a regional sense it may be possible to make "reasonable further progress" toward attaining ambient standards by improving the air in one place while degrading it in another. The flexible terminology appears to allow case-by-case determination whether such a tradeoff does in fact represent "reasonable further progress." In a statute characterized by a lamentable rigidity, ${ }^{221}$ this latitude is a welcome rarity; one only can wish Congress had provided for EPA review of state permit decisions to assure that the underlying policies are carried out.

How the offset provision works can be illustrated by a few examples. Suppose the owner of a steel mill presently meeting plan requirements wants to construct a new basic-oxygen furnace on the same site. If the region where the mill is located exceeds ambient particulate standards, the owner may obtain the necessary offset credit by shutting down a set of open-hearth furnaces in the existing mill, or by fitting them with additional control equipment not required by the plan, if the resulting reduction of open-hearth emissions sufficiently exceeds the new basic-oxygen emissions to "represent reasonable further progress" toward achieving the ambient standard. If the new plant is to be built at a considerable distance from the old one, the different impacts of the old and new emissions on ambient quality will have to be taken into account in determining whether "reasonable further progress" is being made.

Even if our steelmaker has no existing emissions of its own that can practicably be reduced, it may benefit from the offset provisions, for the statute does not require that the source reducing its emissions be owned or operated by the person seeking to build the new one. Section 173(1)(A) refers to "total allowable emissions from existing

217. 42 U.S.C. $\$ 7503(1)$ (A) (Supp. I 1977).

218. 41 Fed. Reg. 55529 (1976).

219. Citizens in Long Beach, California, for example, unsuccessfully objected to an offset on the ground that while it might improve air quality generally, it would worsen conditions in the immediate area upwind of the source of the emissions that were to be reduced. See note 224 infra and accompanying text.

220. 42 U.S.C. $\& 7503(1)(A)$ (Supp. I 1977).

221. See, e.g., text at notes 53-54, 62-65, 87-88, 96-102, \& 121-22 supra. 
sources in the region,"222 and the EPA's guidelines explicitly allowed offsets based on reductions from sources owned by others. ${ }^{223}$ The logic of the guidelines is impeccable; as long as net emissions are reduced it is immaterial who reduces them. In this way the statute creates a market in emission rights, making private ingenuity work toward improving the air. Thus our steelmaker, unwilling to retire its own open-hearth furnaces, may be able to pay the owner of a nearby foundry to close down a marginal furnace, to control it beyond plan requirements, or to move to another region. Such a contractual offset was recently reported on a large scale in Long Beach, California: The state agency permitted a corporation to construct a new marine terminal after it agreed to pay $\$ 78,000,000$ to improve emission control at a neighboring power plant and at a number of dry-cleaning establishments. ${ }^{224}$

The pre-1977 EPA guidelines, however, expressly forbade "banking" of emission reductions for offset against future new sources: "Once an emission offset has been executed for a particular new source, there can be no left-over credit to 'bank' for additional new source growth in the future."225 Thus, if our steelmaker claimed credit toward one new furnace when it closed an old mill last year, it could not claim from that closing additional credit toward construction of another furnace this year even if last year's emission reductions were great enough to have justified three or four new furnaces.

The EPA's explanation was that offset banking "would be inconsistent with a basic policy of the Act and the ruling - namely, that at a minimum, no new source should be allowed to make existing [ambient] violations any worse."226 But industry correctly pointed out that the refusal to allow banking penalized conscientious owners who had already installed the best emission controls, forcing them to look elsewhere for offset credit while their dawdling competitors received credit for reductions they should have already achieved. Moreover, the no-banking rule operated as an incentive to delay implementing additional control measures until the owner needed the reduction to offset expansion. Persuaded by these arguments, the EPA revised its interpretation after the adoption of the 1977 Amendments to allow banking of offset reductions, ${ }^{227}$ and it has incorpo-

222. 42 U.S.C. $\$ 7503(1)(A)$ (Supp. I 1977).

223. 41 Fed. Reg. 55530 (1976).

224. See 9 ENVIR. REP. (BNA) 691 (1978); 9 ENVIR. REP. (BNA) 2387 (1979).

225. 41 Fed. Reg. 55529 (1976).

226. Id. at 55526.

227. 44 Fed. Reg. 3285 (1979). 
rated that ruling in its guidelines for section 173.228

\section{b. The Alternative to Offset}

Section 173(1)(B) allows the states an alternative to the case-bycase offset policy if their plans incorporate overall limits for newsource emissions that are counterbalanced by plan provisions that will reduce existing emissions enough to make "reasonable further progress" toward the ambient standard.229 Unfortunately, the legislative history sheds little light on this vague provision. It first appeared in the House bill, 230 but the House Report does not explain its operation, saying only that it would allow "greater flexibility" than the EPA's existing offset policy. ${ }^{231}$

While speculation is hazardous, another example may illustrate the basic outline of what Congress had in mind. If a state must reduce existing emissions by 2000 tons per year to achieve ambient standards, it may choose in its revised plan to allow an additional 1000 to be emitted by new sources if it adopts a plan provision requiring reductions totaling 3000 by the 1982 deadline, as long as each intervening year brings a roughly proportional net reduction. How the state distributes the burden of reductions is left largely to its own judgment, subject to the overriding requirement of "reasonable further progress."232 In short, like the other provisions of the 1977 Amendments, the nonattainment provisions exemplify the patchwork, crisis-responsive drafting that is characteristic of the Clean Air Act. ${ }^{233}$

228. 44 Fed. Reg. 20380 (1979). The statutory offset language, governing new plans, requires a comparison of allowable emissions "at the time the new source is to commence operation" with those "prior to the application" for its construction. Banking is not specifically addressed, and "prior to the application" could be taken to refer to any time before application, implying that banking is permissible. The Committee Reports are silent. Though the most natural reading is that the relevant comparison is with emissions immediately prior to application, the EPA's interpretation is certainly reasonable enough to be sustained under Train v. National Resources Defense Council, 421 U.S. 60 (1975).

229. 42 U.S.C. \& 7503(1)(B) (Supp. I 1977).

230. See H.R. Rep. No. 294, 95th Cong., 1st Sess. 388 (1977).

231. Id. at 211, 213, reprinted in [1977] U.S. CoDE CONG. \& AD. News 1077, 1290, 1292.

232. The plan proposed by Illinois on April 1, 1979, is suggestive. While Illinois intends to rely principally upon case-by-case offsets, it has planned existing-source reductions sufficient to cover a "growth allowance," which may be drawn upon by new sources unable to obtain offsets. See (Draft) State Implementation Plan for the State of Illinois, vol. 1, p. 5-4 (1979).

233. The problem of new sources is complicated by the existence of an entirely separate permit system for major new sources in attainment areas, designed to prevent "significant deterioration" of areas now clean. Clean Air Act, Part C, Subpart I, 42 U.S.C. $\$ \$ 7470-7479$ (Supp. I 1977). Because an area may be designated as "attainment" for one pollutant and "nonattainment" for another, a single source may require two permits under the same statute. Moreover, there are numerous large and small differences in the provisions respecting the two permit systems, including the definitions both of "major" sources and of the required control 


\section{CONCLUSION}

The bewildering menagerie of partial relief provisions in the 1977 Act promises to be a rich source of expensive and time-consuming litigation. Moreover, while the amendments have avoided immediate economic catastrophe by alleviating the most acute problems of prior law, they provide only temporary symptomatic relief for the continuing malady of statutory inflexibility. By placing absolute deadlines in the new DCO and nonattainment provisions, ${ }^{234}$ for example, Congress virtually assured itself of facing the same problems again during the 1980s.

It is tempting to say that Congress has failed to learn from its mistakes. Experience with the initial set of ambient standards has shown the likelihood that the statutory schedule will be unrealistically tight in a number of cases. The obvious remedy, I have argued, is a general provision allowing individual variances or categorical relaxation of standards for unreasonable hardship. Yet Congress in 1977 not only failed to enact such a provision; it deliberately shut off the general safety valve the EPA had discovered in the "reasonable time" provision of section 113(a)(4). ${ }^{235}$ The stopper is section $110(\mathrm{~h})$ :

Except for a primary nonferrous smelter order under section 119 of this title, a suspension under section $110(\mathrm{f})$ or $(\mathrm{g})$ of this section (relating to emergency suspensions), an exemption under section 118 of this title (relating to certain Federal facilities), an order under section 113(d) (relating to compliance orders), a plan promulgation under section 110 (c) of this section, or a plan revision under section 110(a)(3) of this section, no order, suspension, plan revision, or other action modifying any requirement of an applicable implementation plan may be taken with respect to any stationary source by the State or by the Administrator. ${ }^{236}$

Despite the Senate Committee's blustering statement in 1970 that "existing sources . . . should meet the standard of the law or be closed down,"237 the relief granted in 1977 shows that massive closings were not what Congress had in mind. It seems much more probable that Congress set absolute deadlines in order to create an

technology. It would have made more sense to require a single permit for major new sources of regulated pollutants anywhere, making clear that the determination of technology and cost could vary according to the need for control in the particular area, and requiring a showing that the new source would neither contribute to significant deterioration of clean areas nor impede reasonable progress toward attainment in dirty ones.

234. 42 U.S.C. $\$ 7413$ (d) (Supp. I 1977) (delayed-compliance orders); 42 U.S.C. $\$ 7502$ (Supp. I 1977) (nonattainment areas).

235. Clean Air Amendments of 1970, § 113(a)(4) (repealed 1977). See text at note 19 supra.

236. Clean Air Act Amendments of 1977, § 110(h), 42 U.S.C. § 7410(i) (Supp. I 1977).

237. S. ReP. No. 1196, 91st Cong., 2d Sess. 3 (1970). 
incentive for the development of new and better technology, reserving to itself the sole power to make adjustments in case good-faith efforts failed to do the trick. This was the explanation for the rigid deadlines for motor-vehicle emissions in section 202(b), which Congress set with full knowledge that the technology was not yet available. ${ }^{238}$ Similarly, the Supreme Court has described the implementation-plan provisions as "technology-forcing." 239 And no doubt Congress was right in perceiving that the desired incentive was significantly enhanced by the fact that in order to relax the deadline, industry had to persuade Congress itself, not simply the EPA, that it had done all it could. ${ }^{240}$ Whether the additional incentive is great enough to justify the costs of statutory complexity and continual amendment is a question on which reasonable people may well disagree.

Whether Congress's aim was to force technology or to ignore the price of absolute health protection, it may have overlooked a significant loophole. Section 110(h) prevents only the states and the Administrator from granting extensions not expressly authorized by statute; it does not limit the traditional power of the courts to consider relative hardship in framing equitable decrees. 241 One district court has already suggested that this authority survives the 1977 Amendments, ordering compliance with a plan requirement only after finding that the necessary equipment was available at reason-

238. 42 U.S.C. \& 7521(b) (Supp. I 1977). See S. ReP. No. 1196, 91st Cong., 2d Sess. 24, 27 (1970). Senator Muskie, sponsor of the vehicle provisions, made clear he anticipated amendment if the technology was not forthcoming. 116 Cong. Rec. 32,905 (1970). See generally Currie, The Mobile-Source Provisions of the Clean Air Act, 46 U. CHI. L. Rev. 811 (1979).

239. Union Elec. Co. v. Environmental Protection Agency, 427 U.S. 246, 257 (1976).

240. See Kramer, The 1977 Clean Air Act Amendments: A Tactical Retreat from the Technology-Forcing Strategy?, 15 URB. L. ANN. 103 (1978). Professor Kramer finds "an inflexible attainment date" a "key ingredient" in a technology-forcing strategy. Accordingly, he views the 1977 liberalization of the explicit variance provisions as a step backward and the rejection of a general variance provision as the legislation's saving grace. Id. at 156-57. He does not contend, however, that the relaxations were unnecessary to avoid unreasonable hardship, or that industry has not made honest efforts to develop better technology. Extensions, if granted only upon a showing of good faith, are not inconsistent with technology-forcing. See note 238 supra. And since the 1977 Amendments still contain absolute deadlines, even Professor Kramer acknowledges that they "refiect more a mid-course correction for the technology-forcing strategy initially mandated in 1970 than a total rejection," Kramer, supra at 156.

241. See, e.g., Boomer v. Atlantic Cement Co., 26 N.Y.2d 219, 257 N.E.2d 870, 309 N.Y.S.2d 312 (1970) (cost of abating nuisance); Reserve Mining Co. v. Environmental Protection Agency, 514 F.2d 492 (8th Cir. 1975) (tempering with cost considerations the absolute language of the Refuse Act, 33 U.S.C. $\$ 407$ (1976), in formulating a remedy). For dicta suggesting that such considerations were relevant in framing judicial remedies under the imple. mentation-plan provisions prior to 1977 , see Indiana \& Mich. Elec. Co. v. Environmental Protection Agency, 509 F.2d 839, 845 (7th Cir. 1975); Friends of the Earth v. PEPCO, 419 F. Supp. 528, 535 (D.D.C. 1976). Contra, United States v. United States Steel Corp., 9 ENvir. REP. (BNA) 1002, 1005 (N.D. Ala. 1976). See Currie, Federal Air-Quality Standards and Their Implementation, 1976 A.B.F. RES. J. 365, 405-06. 
able cost. ${ }^{242}$

Thus if Congress really means to shut down noncomplying sources without regard to hardship, it may have to say so more explicitly. It would be better, however, to replace the present procrustean structure with a single provision allowing variances for those who in good faith cannot comply without unreasonable hardship.

242. See United States v. West Penn Power Co., 460 F. Supp. 1305, 1307-12, 1313-14 (W.D. Pa. 1978). 